\title{
Productivity Growth and Interest Rate Trends: A Long-Run Analysis
}

\author{
Dmitriy Stolyarov
}

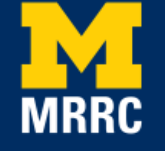

Project \#: R-UM16-Q2 


\title{
Productivity Growth and Interest Rate Trends: A Long-Run Analysis
}

\author{
Dmitriy Stolyarov \\ University of Michigan \\ December 2016 \\ Michigan Retirement Research Center \\ University of Michigan \\ P.O. Box 1248 \\ Ann Arbor, MI 48104 \\ www.mrrc.isr.umich.edu \\ (734) 615-0422
}

\section{Acknowledgements}

The research reported herein was performed pursuant to a grant from the U.S. Social Security Administration (SSA) funded as part of the Retirement Research Consortium through the University of Michigan Retirement Research Center Award RRC08098401. The opinions and conclusions expressed are solely those of the author(s) and do not represent the opinions or policy of SSA or any agency of the federal government. Neither the United States government nor any agency thereof, nor any of their employees, makes any warranty, express or implied, or assumes any legal liability or responsibility for the accuracy, completeness, or usefulness of the contents of this report. Reference herein to any specific commercial product, process or service by trade name, trademark, manufacturer, or otherwise does not necessarily constitute or imply endorsement, recommendation or favoring by the United States government or any agency thereof.

\section{Regents of the University of Michigan}

Michael J. Behm, Grand Blanc; Mark J. Bernstein, Ann Arbor; Laurence B. Deitch, Bloomfield Hills; Shauna Ryder Diggs, Grosse Pointe; Denise Ilitch, Bingham Farms; Andrea Fischer Newman, Ann Arbor; Andrew C. Richner, Grosse Pointe Park; Katherine E. White, Ann Arbor; Mark S. Schlissel, ex officio 


\title{
Productivity Growth and Interest Rate Trends: A Long-Run Analysis
}

\begin{abstract}
This paper develops a new measure of after-tax rate of return on aggregate wealth and uses it in estimating the structural relationship between the long-run interest rate and productivity growth rate. The structural approach allows use of parameter estimates in constructing projections for the interest rate on U.S. Treasury securities. Results indicate that the long-run interest rate rises slightly more than one for one with productivity growth rate. The projected real interest rate on 10-year US government bonds is in the 1.5-2.0 percent range under intermediate assumptions on future productivity growth and trends in the world interest rate.
\end{abstract}

\section{Citation}

Stolyarov, Dmitriy. 2016. "Productivity Growth and Interest Rate Trends: A Long-Run Analysis.” Ann Arbor, MI. University of Michigan Retirement Research Center (MRRC) Working Paper, WP 2016-357.

http://www.mrrc.isr.umich.edu/publications/papers/pdf/wp357.pdf 


\section{Introduction}

Many observers noted that global interest rates have been declining for several decades, with real interest rates moving into a negative territory most recently. Other analysts raise related concerns about slow productivity growth that may be one reason for the observed interest rate decline. These observations raises the question of how to interpret these trends and how to incorporate the new evidence into the long-run interest rate projections.

The question is challenging, in part, because it may be difficult to translate observed rates of return on financial assets into a proxy for the long-run interest rate. For instance, the interest rate on US Treasury securities may be sensitive to variations in global demand for safe assets. Demand for safe assets may itself exhibit time trends, making interest rate movements hard to interpret. Recent studies (e.g. Bernanke et al. [2011] and Hall [2016]) point out several factors that recently pushed up demand for safe assets potentially driving down the interest rate. The evidence is not clear, however, on whether the elevated demand for safe assets will persist or for how long. This uncertainty makes it difficult to project the long-run interest rate from historical trends in the market for Treasury securities. As an alternative, one can look at other financial rates of return, particularly at stock returns, for useful information on the long-run interest rates. One approach in the previous literature uses stock returns in the estimation of a consumption-based asset pricing model. The estimated model can then inform on the long run relationship between the interest rate and the productivity growth rate. It turns out, however, that the comovement between consumption and stock returns is hard to rationalize in the context of the consumption-based asset pricing model, particularly because it is hard to reconcile high stock return volatility with relatively low consumption volatility. In some cases, the estimates obtained are outside of what is thought to be plausible ranges for parameter values. Thus constructing interest rate projections 
using stock returns data is difficult. The results from prior work seem to suggest that one might need to examine the definition of the rate of return to properly apply the standard model.

This paper aims to justify the interest rate projections with historical evidence on economic performance interpreted through the lens of the neoclassical growth model - a standard, workhorse model used in macroeconomic analyses. The standard model interprets the interest rate variable as the after-tax rate of return on total wealth. Consistent with this interpretation, I apply the standard model to the tax-adjusted rate of return on an investment portfolio consisting of the total private business assets of the US economy and its government debt.

The main innovation is in using detailed annual National Income and Product Accounts (NIPA) data in the construction of an interest rate composite that serves as a proxy for the after-tax interest rate. The interest rate composite thus obtained is shown to explain consumption data better than either return on equity or interest rate on Treasury bonds, and the newly derived parameter estimates for the standard model fall in line with the values obtained with other, independent, methods. This improves on the earlier approaches that found puzzling inconsistencies between the consumption-based asset pricing model and the interest rate definitions based on financial rates of return.

The baseline estimates for the real interest rate on 10-year US government bonds are in the 1.5-2.0 percent range (see Table 3). This is lower than the intermediate-cost assumption of 2.5 percent in the 2015 Technical Panel on Assumptions and Methods (TPAM) report, for two reasons. First, there is evidence that the intermediate assumption of 1.7 percent annual productivity growth is somewhat optimistic - recent studies lend support to lower estimates for future productivity growth. Second, global trends in productivity growth and population growth can bring about future interest rate declines across the world and prevent the rates on US Treasury securities from rising. 
Two main sources of uncertainty affect long-run interest rate projections. The first has to do with the future rate of productivity growth. A recent body of research supports annual labor productivity growth in the 1.0-1.4 percent range going forward, although some optimistic assessments envision future productivity growing at 1.8 percent annually. Assumptions underlying optimistic productivity growth projections of a few years ago do not seem to be widely supported in studies that appeared since. What is more, estimates of the rate of technological progress - the ultimate driver of productivity growth may be biased upwards because of unmeasured investment in intangible capital. All other things equal, a sources of growth decomposition that accounts for unmeasured intangible capital implies a 0.3 percent slower rate of long-run productivity growth than the same method using national accounts data. Intangible capital accumulation remains an important source of growth, having contributed over 0.5 percent to productivity growth during 1995-2013. If intangible capital investment share in GDP does not go down, capital deepening would give productivity growth a boost in the medium run.

Demand for US Treasury securities depends on the world interest rate that summarizes alternative investment opportunities. Accordingly, the second source of uncertainty has to do with international financial flows that contributed to recent high demand for US government bonds and are thought to have contributed to interest rate declines after 2000. Several studies point out that a combination of slowing population growth and lower productivity growth would cause a slowdown in global investment demand. This paper uses UN country-level population projections and presents a range of simulations where slower growth of investment demand across the world causes the global interest rate to fall by 100-150 basis points in the next 25 years. It is unclear how much of this interest rate decline will be passed through to the US Treasury securities - the answer will depend not only on the world interest rate level, but also on global demand for safe assets generally. 
Increased borrowing by the US government over the next 30 years projected by the CBO could push interest rates upwards by 40-50 basis points, partially offsetting the effects of projected global developments on the world interest rate.

All told, long-run projections with intermediate assumptions show the real interest rate on 10-year US government bonds in the 1.5-2.0 percent range, which is lower than its 2.3 percent historical average (1953-2015). This range can be justified as follows. If future productivity growth were 1.7 percent, as in intermediate-cost TPAM report assumption, structural estimates in Table 3 would imply a 2.2-2.6 percent range for the real interest rate on bonds. Starting from this range, analysis shows that one should subtract 50-60 basis points due to lower baseline productivity growth, subtract a further 60 basis points due to projected world population growth slowdown and add 40-50 basis points due to projected rise in the US debt-to-GDP ratio.

The paper proceeds as follows. Section 2 constructs the rate of return on equity in the US private business sector and compares its time series with that for the interest rate on bonds; Section 3 describes a model-based method for constructing the long-run interest rate projections, estimates the model and presents long-run interest rate estimates under alternative scenarios; Section 4 reviews the literature on future productivity growth and quantitatively investigates the role of intangible capital in measuring the sources of US productivity growth; Section 5 constructs the rate of return of equity for 70 largest world economies and uses the UN population projections to simulate the impact of future population growth on the world interest rate.

\section{Comparisons of interest rate measures and interpretations of recent trends}

This section describes how the rate of return on equity is constructed from national accounts data, and it compares trends in rates of return on equity and bonds over the past 60 years. The main finding is that the equity risk premium rose substantially during 2000-2015 as the interest rate on bonds declined. This 
result is discussed in the context of recent literature on interest rates to provide insights into the nature of this trend.

\subsection{Constructing rate of return on equity in the US business sector}

The rate of return on equity is calculated from the national accounts data for the US private business sector. This method produces a rate of return measure that is independent of financial markets data. What is more, national accounts-based interest rate maps naturally into the standard neoclassical model making it straightforward to use in structural estimation.

RATE OF RETURN DEFINITION We start with applying a standard rate of return definition to the total assets of US non-farm business sector. The analysis uses a conventional definition of the ex-post realized rate of return,

$$
r_{e, t}=\frac{y_{t}+V_{t+1}-V_{t}}{V_{t}}
$$

where $y_{t}$ is the net income derived from the asset in the current period, $V_{t}$ is the date- $t$ tax-adjusted value of the asset, and $V_{t+1}-V_{t}$ is the ex-post capital gain. The net income is value added output less taxes on output and corporate income, consumption of fixed capital and labor compensation. To construct the tax-adjusted asset value $V_{t}$, one needs to make further analytical steps detailed in Appendix A. The essential elements of the tax-adjustment procedure are described below.

TAX ADJUSTMENTS AND INTANGIBLE CAPITAL The rate of return is adjusted for corporate tax - but not for income tax - to be directly comparable to the financial market bond interest rates. Corporate tax rate alone is insufficient to make the tax adjustment, because tax treatment of investment expenditure differs by asset type. Investment expenditures on a physical asset, for instance, are deducted from future taxable income as the asset depreciates. By contrast, investment expenditures on intangible capital are deducted from current profits, as if the asset fully depreciated in the current period. Accordingly, special attention 
is paid to the distinction between physical capital - equipment and structures - and intangible assets consisting of multiple categories of intellectual property (see, for example, Table 6). The tax-adjustment method allows to express the unobserved rate of return on equity through the observed components of national accounts using the theoretical framework of McGrattan and Prescott [2005].

\subsection{Rate of return on equity- results and discussion}

Figure 1 compares the pre-tax and after tax rates of return on equity in the US business sector during 1953-2015. Both levels and time trends are substantially different, the reason having to do with the timevarying effective corporate tax rate (see also McGrattan and Prescott [2005]). The pre-tax rate of return, for example, shows a downward trend prior to 1973. The after tax rate of return shows no such trend, primarily because the effective average tax rate on corporate income has been falling throughout the sample period. This result is robust under alternative definition of intangible capital ${ }^{1}$

The constructed rate of return on equity is independent of financial market variables. As such, it could reveal new information about potential reasons for the observed decline in global interest rates. Numerous studies have noted that the interest rates across the world have been falling since the 1980s. (e.g. IMF [2014], King and Low [2014], Rachel and Smith [2015], Eggertsson et al. [2016] among many others). As it turns out, the rate of return on equity in the US did not decline in step with the global interest rates. On Figure 1, the after-tax return on equity stayed relatively flat in the 1980s and 1990s, and it edged up after 2000. Over the past 15 years, in fact, the equity return was 100 basis points higher than its long-run average: 6.7 percent per year during 2000-2015 compared to 5.7 percent per year over

\footnotetext{
1 The rate of return on equity changes little when an expanded definition of intangible capital is used: the average difference between $r_{e}^{+}$(derived from NIPA+ asset classes as defined in Section 5.1) and $r_{e}$ on Figure 1, is 20 basis points, with the maximum difference of about 60 basis points. Intangible capital definition matters less for the rate of return, it turns out, than it does for the sources of growth decomposition (see Section 5.1, Figure 7) The roughly equal rates of return on NIPA and NIPA+ assets imply that real intangible capital stock grows at the rate approximately equal to the rate of return. This, in turn, indicates that intangible capital accumulation contributes positively to productivity growth. See Section 5.2.
} 
the 1953-2015 sample period. Detailed analysis of the underlying NIPA data reveals that two factors worked in concert to push up equity return over the past 15 years - the falling corporate tax rate and the falling labor share. The average effective corporate tax rate fell precipitously - from 33 percent in 2000 to just 21 percent in 2015, dipping as low as 16 percent in 2009-2010. The falling corporate tax rate contributed about 160 basis points to the equity return; if the effective corporate tax rate stayed as its 2000 level, the return on equity would have been 5.1 percent rather than 6.7 percent. During the same time period, the NIPA labor share fell from 0.68 in 2000 to 0.63 in 2015, and this fall contributed about 90 basis points to the return on equity. If both corporate tax rate and labor share stayed at their 2000 levels, the return on equity over the past 15 years would have been just 4.2 percent rather than 6.7 percent.

Figure 1. Comparison of pre-tax and after-tax rates of return on NIPA capital, $r_{k}$.

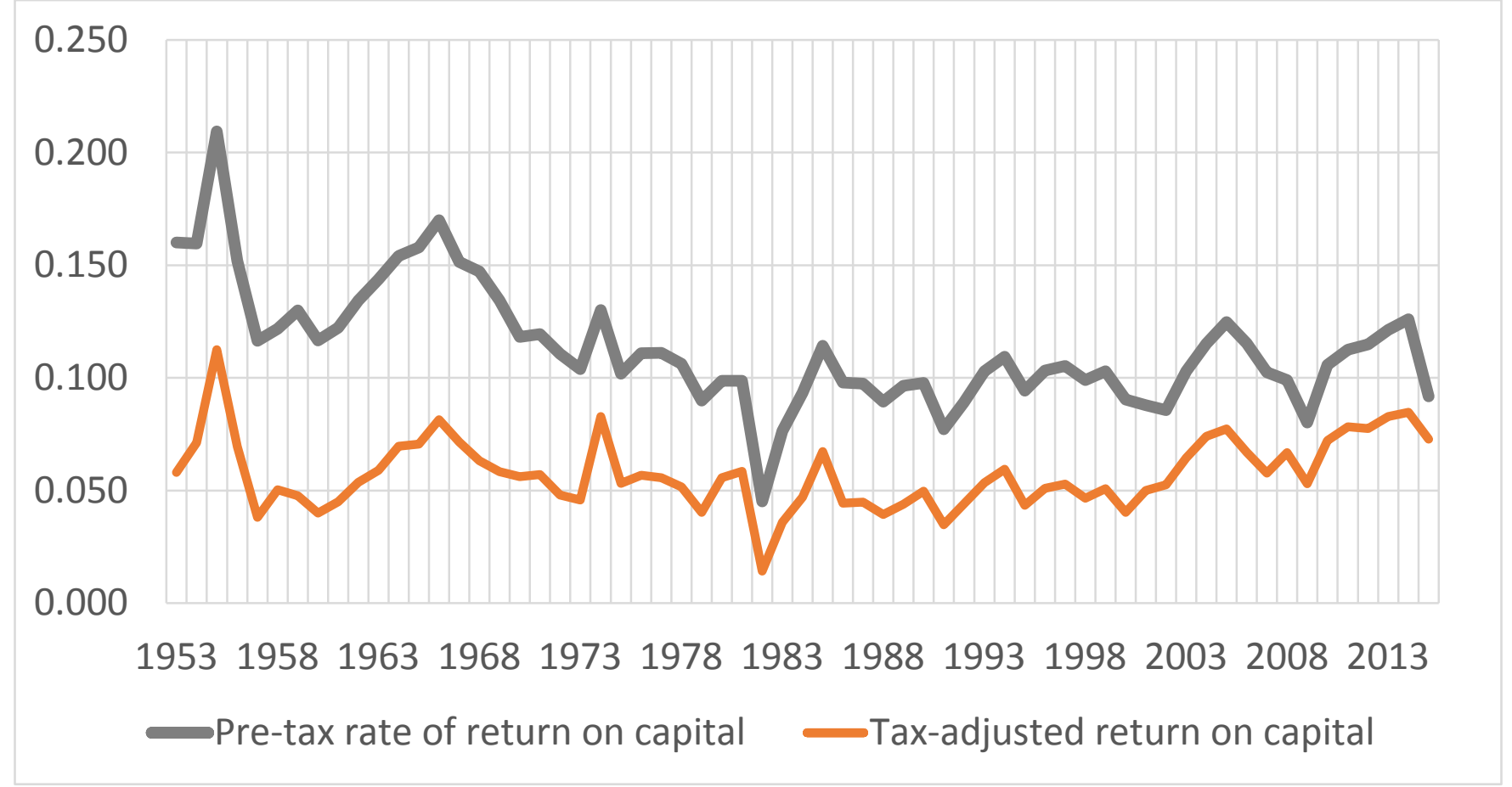

Analysis over sub-periods reveals other regularities. Table 1 compares the NIPA-derived rate of return on equity with financial market rate of return measures: the real interest rate on 10-year Treasury bonds 
and the rate of return on S\&P 500 over the 20-year sub-periods. In theory, one would expect the period averages of $r_{e}$ and the rate of return on S\&P 500 to be close but not identical since S\&P 500 covers only a subset of firms in the US business sector. Table 1 shows that the two rates of return are close to one another, with the exception of 1953-1973 when the S\&P 500 return exceeded the US business sector return by almost 300 basis points per annum.

Table 1. Rate of return comparison over sub-periods.

\begin{tabular}{|l|c|c|c|c|c|}
\hline & $\mathbf{1 9 5 3 - 1 9 7 3}$ & $\mathbf{1 9 7 4 - 1 9 9 4}$ & $\mathbf{1 9 9 5 - 2 0 1 5}$ & $\mathbf{1 9 5 3 - 2 0 1 5}$ & $\mathbf{1 9 7 4 - 2 0 1 5}$ \\
\hline Rate of return on S\&P 500 & 0.089 & 0.049 & 0.066 & 0.068 & 0.058 \\
\hline $\begin{array}{l}\text { Rate of return on capital, } \\
\boldsymbol{r}_{\boldsymbol{e}}\end{array}$ & 0.060 & 0.049 & 0.061 & 0.057 & 0.056 \\
\hline $\mathbf{1 0}$-year Treasury rate, $\boldsymbol{r}_{\boldsymbol{b}}$ & 0.021 & 0.027 & 0.020 & 0.023 & 0.023 \\
\hline Risk premium, $\boldsymbol{r}_{\boldsymbol{e}}-\boldsymbol{r}_{\boldsymbol{b}}$ & 0.039 & 0.022 & 0.041 & 0.035 & 0.033 \\
\hline
\end{tabular}

The 1974-1994 sub-period seems unusual in that the risk premium on NIPA equity over bonds was much lower than either before or after. We see in Table 1 that both low equity return and high bond return played a role. A more detailed look at the NIPA data reveals that the return on equity was low for two reasons: modest productivity growth and higher-than-average depreciation of physical capital. The latter could be due to replacement of obsolete equipment precipitated by the oil price spike of the late 1970s and the onset of the information-technology revolution. In line with this, NIPA equipment deflator shows a steep decline - suggesting that older equipment types faced stiff competition from modern equipment which, in turn, led to accelerated depreciation.

\section{PERSPECTIVES ON THE GLOBAL INTEREST RATE DECLINE - A REVIEW OF ALTERNATIVE HYPOTHESES}

The divergent trends between the return on equity in the US and the interest rate on Treasury bonds (see Figure 2 below that plots the two series together) suggest that the rising risk premium played a large role in the observed interest rate decline. Several recent analyses put forward alternative hypothesis for the 
rising risk premium. Caballero et al. [2008] and Caballero and Farhi [2014] rationalize the recent high risk premium based on inability of some economies to produce safe assets. Hall [2016] explains the rising risk premium with the rising fraction of risk-averse investors, and he points to the bond-heavy portfolios of foreign investors in the US assets as evidence. For example, as of 2015, China, Japan and Taiwan each held more than 80 percent of their US assets in Treasury securities.

There are several related hypotheses explaining the interest rate decline. Bernanke et al. [2011] note that safe asset shortage in the foreign economies together with other factors might have increased financial flows from abroad that they term the "saving glut”. As the supply of loanable funds in the US market increased, the interest rate dropped. Foreign capital flows to the US may partly be a result of global productivity slowdown depressing returns on equity across the world. Section 4 examines this channel in detail and assesses the effect of world productivity growth on global interest rate.

Summers [2014] points out multiple reasons for slowing demand for debt-financed investment driven by (i) declining labor force growth, (ii) a possible slowdown in the rate of technological progress (e.g. Gordon [2014, 2016]), (iii) the declining price of capital goods and by (iv) substitution of physical capital with intangible capital in production.

\section{FALLING PRICE OF CAPITAL GOODS, THE INTEREST RATE TREND AND THE EQUITY PREMIUM} Eichengreen [2015] examines the relative importance of the alternative hypotheses above. He first points out - somewhat contrary to the analyses in IMF [2014] and Rachel and Smith [2015] - that the extent of the interest rate decline observed since the 1980s may partially reflect mean reversion rather than trend. In fact, the real annual ex-post rate of return on Treasuries had spiked to above 7 percent in 1984-85, reaching the heights not seen since the Great Depression. ${ }^{2}$ The interest rate spike puzzled the analysts at the time (e.g. Blanchard and Summers [1984]), lending some support to Eichengreen's view that the

\footnotetext{
${ }^{2}$ Source: online data compiled by Robert Shiller and author's calculations.
} 
high interest rates of the early and mid-1980s were somewhat of an exception. To evaluate the "saving glut” hypothesis, Eichengreen [2015] presents data on global saving rates going back more than a century and argues, based on historical trends, that the post-2000 "saving glut" appears to be temporary. ${ }^{3}$ Two arguments may support this view. Frist, as developing countries grow and their institutions mature, demand for safe assets may shift away from US bonds. Second, aging population in developed countries may lead to lower personal saving rates and relieve the saving glut. may relieve the saving glut. ${ }^{4}$ Looking at the historical data since 1870, Eichengreen [2015] observes that the relative price of investment goods experienced its first trend break - and a sustained sharp decline - beginning in the 1980s, at about the same time when the interest rates started to fall. Accordingly Eichengreen's analysis lends additional support to the falling investment price as a driver of the interest rate decline.

At the same time, the rate of decline in the relative price of equipment appears to be slowing down most recently. This relative price declined by about 0.1 percent per year between 1948-1978, by 3.0 percent per year between 1978 -2008 and by 0.8 percent per year since $2008 .{ }^{5}$ It remains to be seen whether the relative price of capital is having another trend break. If so, this might stem the interest rate decline.

It is worth noting that the falling price of capital goods might have indirectly contributed to the rising risk premium. This paper’s analysis shows, for instance, that the falling labor share can account for 90 basis points of the equity premium. According to Karabarbounis and Neiman [2013], the underlying decline in the labor share might have been caused by a drop in the relative price of capital goods that led to substitution of capital for labor. In line with this, Beaudry et al. [2013] note the decline in demand for cognitive tasks that occurred after 2000. As workers who used to perform cognitive tasks moved down the occupation ladder, the overall labor share declined.

\footnotetext{
3 This observation informs the construction of the average risk premium used in deriving the long-run interest rate projections. See Section 3.3.

${ }^{4}$ See Carvalho et al. [2016] for a quantitative assessment of this effect based on evidence from developed countries.

${ }^{5}$ Source: NIPA tables 2.3.4., 5.3.4. and author's calculations.
} 
To summarize, the rate of return on equity in the US private business sector and the interest rate on bonds show diverging trends over the last 15 years, leading to recent risk premia on equity over bonds near the historic high. One contributor to the high risk premium is the falling price of capital goods. Cheaper capital goods can raise the return on equity - through replacing labor with capital and reducing the labor share - as well as lower the interest rate on bonds - through moderating demand for debtfinanced capital expenditure. International capital flows are thought to be another major factor behind the recent interest rate decline in the US. The detailed discussion of the global drivers of interest rate decline is left to Section 4. We now proceed to use the data on equity returns, the interest rate and the risk premium to construct long-run interest rate projections.

\section{Long-run interest rate projections}

This paper proposes to construct long-run interest rate projections using the standard neoclassical growth framework - a workhorse model describing long-run macroeconomic phenomena. A key step is to estimate the model's parameters from aggregate data on consumption and interest rates. Special attention is given to the correspondence between the data constructs used in the estimation and the definitions of variables in the structural model. Accordingly, we start with closely examining the interest rate concept to be used in the estimation.

In the neoclassical growth model, aggregate consumption depends on (i) the aggregate wealth and (ii) the after-tax rate of return on wealth. The model-data correspondence thus requires an interest rate measure that proxies for the average rate of return on wealth in the US. Define the interest rate composite as the rate of return on an investment portfolio consisting of the entire business sector of the US economy and its total government debt. ${ }^{6}$ The average rate of return on equity in the US business sector may be a proxy for economic activity that is related to household income and economic

\footnotetext{
${ }^{6}$ This measure of aggregate wealth excludes the market value of owner-occupied housing to maintain consistency between the definition of aggregate wealth and the definition of labor productivity.
} 
expectations, whereas the rate of return on government debt may co-move with household borrowing costs.

\subsection{Interest rate composite}

As stated above, the composite interest rate is a weighted average of rate of return on equity in the US private business sector and the interest rate on US government debt:

$$
r_{c, t}=s_{b, t} \cdot r_{b, t}+\left(1-s_{b, t}\right) \cdot r_{e, t},
$$

The debt share, $s_{b, t}$, is calculated from the market value of business sector capital ( $\widetilde{K}_{t}$ for tangible and $\widetilde{M}_{t}$ for intangible) and the total US government debt, ${ }^{7} \tilde{B}_{t}$ :

$$
s_{b, t}=\frac{\tilde{B}_{t}}{\widetilde{K}_{t}+\widetilde{M}_{t}+\widetilde{B}_{t}}
$$

\footnotetext{
${ }^{7}$ Source: US Treasury public debt report, various years.
} 
Figure 2. 10-year bond yield, rate of return on equity and the interest rate composite.

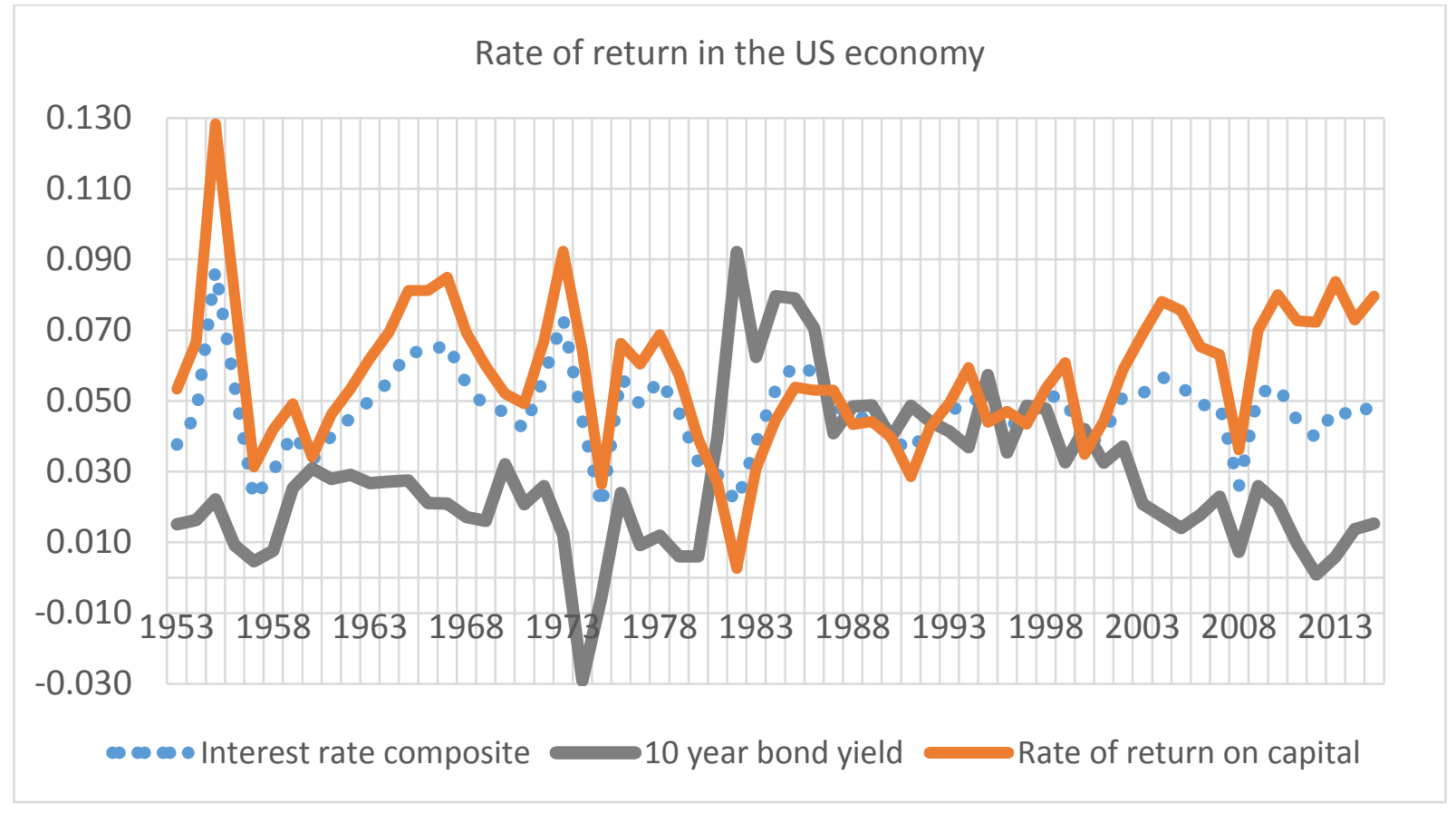

Figure 2 shows the time series for the after-tax rate of return on equity, $r_{e, t}, 10$-year Treasury bond rate $r_{b, t}$ and the interest rate composite $r_{c, t}$ calculate from equation (1). On Figure 2, one can see divergent trends in $r_{e}$ and $r_{b}$ and the growing risk premium after 2000.

Table 2. Rate of return summary statistics

\begin{tabular}{|l|c|c|c|}
\hline & $\boldsymbol{r}_{\boldsymbol{e}}$ & $\boldsymbol{r}_{\boldsymbol{b}}$ & $\boldsymbol{r}_{\boldsymbol{c}}$ \\
\hline Mean, percent & 5.73 & 2.79 & 4.59 \\
\hline Coeff. of variation & 0.35 & 0.76 & 0.25 \\
\hline Correlation with $\boldsymbol{r}_{\boldsymbol{c}}$ & 0.85 & 0.02 & 1.00 \\
\hline Correlation with $\boldsymbol{r}_{\boldsymbol{b}}$ & -0.43 & 1.00 & 0.02 \\
\hline
\end{tabular}

Table 2 reports summary statistics for the interest rate composite and its components. The second line of the table shows that the interest rate composite is less variable than either return on equity or the interest rate on bonds. This is despite the fact that the debt share in (1) is itself time-varying: $s_{b, t}$ fell from 0.40 
in 1953 to about 0.20 in 1980, subsequently it rose to over 0.35 by 1991, stabilized, and then it further rose from 0.35 in 2007 to over 0.45 by 2012.

The interest rate composite is strongly positively correlated with $r_{e}$, and it shows almost zero correlation with $r_{b}$, because the rates of return on equity and bonds are negatively correlated with one another. The negative correlation between $r_{e}$ and $r_{b}$ is of separate interest: it means that the US business sector equity is perceived as relatively more risky when equity returns are high. All three measures of the interest rate will be used in estimating the structural model.

\subsection{Structural relationships}

The neoclassical growth model assumes that households make an optimal consumption-saving choice which results in a linear relationship between the growth rate of per-capita expenditure and the after-tax interest rate. Household optimal behavior in the standard neoclassical model is summarized by the consumption Euler equation:

$$
\Delta \operatorname{lnc} c_{t}=\sigma\left(r_{t}-\rho\right)
$$

Equation (2) depends on two preference parameters, $\rho$ and $\sigma$, which are restricted to both be positive in the neoclassical model. The first parameter, $\rho$, measures the rate of time preference, and its magnitude reflects the degree of impatience of the "average” household in the economy. The second parameter, $\sigma$, reflects the households' tolerance for non-smooth consumption across time periods in response to the variation in the return on saving - the higher is the $\sigma$, the greater is the response of expenditure to the interest rate changes.

In the standard model, aggregate expenditure level depends on both the after-tax interest rate - denoted by $r_{t}$ in equation (2) above - and the aggregate household wealth, whereas the growth rate of per-capita expenditure depends on just the interest rate. 
The neoclassical model interprets $\rho$ and $\sigma$ as preference parameters, but it is hard to identify their values from microeconomic data on households. This is because the neoclassical model considers only aggregate consumption decisions, and it uses the concept of a representative household as a decisionmaker. Microeconomic data, on the other hand, show substantial heterogeneity in risk aversion and discount factors across households, and they provide little guidance on how to obtain the representative household preference parameters from disaggregated data.

The estimation method instead uses the interest rate composite constructed from equation (1) and the per-capita expenditure series taken from the NIPA to estimate parameters $\rho$ and $\sigma$ in equation (2). The estimates reveal the long-run interest rate as follows. In the long run, the standard neoclassical model predicts that per-capita consumption should grow at the same rate as labor productivity - if this was not the case, then the economy would eventually be either spending or saving all of its income. Letting $g$ denote the long-run labor productivity growth rate, the long-run interest rate $\bar{r}$ can be expressed through $g, \rho$ and $\sigma$ using the long-run version of equation (2):

$$
\bar{r}=\rho+\frac{1}{\sigma} g .
$$

Equation (3) makes two predictions: a positive relationship between the long-run interest rate and the long-run productivity growth rate, and a higher sensitivity of the long-run interest rate to the variations in $g$ when households have a stronger preference for smooth consumption (i.e. when $\sigma$ is small). Accordingly, the estimates of $\rho$ and $\sigma$ are informative about the level of the long-run interest rate as well as its sensitivity to the variations in the long-run productivity growth.

\subsection{Estimation results}

Equation (2) is estimated with the 1953-2015 time series for per-person real consumption growth $\Delta \ln c_{t}$ derived from annual NIPA data. Table 3 presents estimated preference parameters for six regression 
specifications. Parameters of interest to be used in constructing the long-run projections with equation

(3) are $\frac{1}{\sigma}$ and $\rho$.

Table 3. Estimated preference parameters; confidence intervals in parenthesis.

\begin{tabular}{|c|c|c|c|c|c|c|}
\hline & Spec 1 & Spec 2 & Spec 3 & Spec 4 & Spec 5 & Spec 6 \\
\hline $\begin{array}{c}\text { Interest } \\
\text { rate } \\
\text { measure }\end{array}$ & $r_{e}$ & $r_{b}$ & $r_{e}$ & $r_{c}$ & $r_{c}$ & $r_{c}$ \\
\hline $\begin{array}{c}\text { Population } \\
\text { measure }\end{array}$ & All & All & Working age & Working age & All & All \\
\hline $\mathbf{1}$ & 16.5 & 3.94 & -21.0 & $\begin{array}{c}1.14 \\
(0.71,1.56)\end{array}$ & $\begin{array}{c}1.15 \\
(0.74,1.57)\end{array}$ & $\begin{array}{c}1.12 \\
(0.78,1.45)\end{array}$ \\
\hline $\boldsymbol{\sigma}$ & -0.27 & -0.06 & 0.51 & $\begin{array}{c}0.02 \\
(0.01,0.03)\end{array}$ & $\begin{array}{c}0.02 \\
(0.01,0.03)\end{array}$ & $\begin{array}{c}0.02 \\
(0.01,0.03)\end{array}$ \\
\hline $\boldsymbol{\rho}$ & 0.006 & 0.09 & 0.004 & 0.31 & 0.32 & 0.42 \\
\hline $\boldsymbol{R}^{\mathbf{2}}$ & 63 & 63 & 63 & 63 & 63 & 61 \\
\hline Nobs & & & &
\end{tabular}

The regression specifications differ in their definitions of the model's variables. Specification 1 , for instance, uses the rate of return on equity as a proxy for the interest rate in equation (2), and specification 2 uses the interest rate on bonds. Two definitions of population - working-age adults and all persons - are both consistent with the standard neoclassical growth model and are used across different specifications. Specification 3, for example, has working-age adults as an alternative population measure.

Specifications 1-3 all produce point estimates that are outside of the admissible range in the neoclassical model (recall that the model assumes that both $\rho$ and $\sigma$ are positive). The low values of $R^{2}$ (row 6 of Table 3) indicate that the rate of return on equity has almost no explanatory power for the changes in per-person consumption. Empirical results with similar features can be found in related literature as well. Numerous prior studies used aggregate consumption data in conjunction with financial market rates of return to estimate parameters $\rho$ and $\sigma$ in the consumption Euler equation. The finding that $\rho$ is negative and the risk aversion coefficient is high (as in specification 1) is typical of prior tests of 
consumption-based asset pricing models with stock returns data (e.g. Kocherlakota [1990, 1996]). Hall [1988] estimates a model similar to specification 2 above and reports a negative value of $\sigma$. One can make an argument that it is inappropriate to use aggregate consumption in conjunction with stock returns since the majority of households do not own stocks. ${ }^{8}$ It turns out that using the interest rate composite as a proxy for the model interest rate significantly improves the fit of the standard neoclassical model. The resulting parameter estimates agree with those in prior studies that use different methodologies.

Specifications 4-6 in Table 3 regress per-person consumption growth on the interest rate composite $r_{c}$. Specification 6 additionally drops the observations during 1974 and 2009 recessions. The fit of the model is much improved, and the time preference parameter $\rho$ is positive, consistent with the standard assumptions. The point estimate of $\rho$ of around 0.02 agrees with the standard value for this parameter used in much of the macroeconomics literature. The estimate of $1 / \sigma$ can be compared to the recent studies by Laubach and Williams [2003, 2016] who estimate an empirical specification motivated by equation (3). Their estimate of $1 / \sigma$ is between 1.01 and 1.06 in the 2003 study and around 1.3 in the 2016 study, which brackets the 1.12-1.15 range of point estimates in Table 3. We shall now use Table 3, specification 4-6 parameter estimates to construct the long-run interest rate projections associated with different future productivity growth scenarios.

\subsection{Long-run interest rate projections}

The method for constructing long-run interest rate projections is as follows. A value of $g$ is fixed based on assumptions about a future productivity growth scenario. Equation (3) with parameter estimates from Table 3 (specification 4-6) is used to predict the long-run interest rate composite $\bar{r}$. Conceptually, $\bar{r}$ is the rate of return on wealth that households require in order to rationally increase consumption

\footnotetext{
${ }^{8}$ Ait-Sahalia et al. [2004] demonstrate that consumption of well-off households who own the majority of stocks in practice fits better with the movements in stock returns. The interpretation of this finding is that there is some empirical support for the consumption-based asset pricing model when the definition of consumption and interest rate are mutually consistent.
} 
expenditure in step with productivity growth. To calculate a predicted long-run interest rate on US Treasury bonds, $\bar{r}_{b}$, one needs to make assumptions on the long-run share of US government debt in total wealth, $\bar{s}_{b}$, and on the long-run equity risk premium $\Delta_{e}$. The long-run interest rate $\bar{r}_{b}$ is calculated from $\bar{r}$ using its definition in equation (1): the equity premium times the equity share in total wealth is subtracted from the required rate of return $\bar{r}$ to obtain the rate on bonds:

$$
\bar{r}_{b}=\bar{r}-\left(1-\bar{s}_{b}\right) \Delta_{e}
$$

Table 4. Long-run interest rate projections under alternative assumptions.

\begin{tabular}{|c|c|c|c|c|c|c|}
\hline Growth rate projection source & $\begin{array}{l}\text { Gordon } \\
\text { [2014] }\end{array}$ & $\begin{array}{l}\text { TPAM } \\
\text { high } \\
\text { cost }\end{array}$ & $\begin{array}{l}\text { TPAM } \\
\text { interm. } \\
\text { cost }\end{array}$ & $\begin{array}{l}\text { Byrne et } \\
\text { al. } \\
\text { [2013] }\end{array}$ & $\begin{array}{l}\text { TPAM } \\
\text { low cost }\end{array}$ & $\begin{array}{l}\text { Hist. } \\
\text { average }\end{array}$ \\
\hline Assumed productivity growth rate, $g$ & 1.2 & 1.4 & 1.7 & 1.8 & 2.0 & 2.1 \\
\hline $\bar{r}$ from equation (3) & 3.5 & 3.7 & 4.0 & 4.2 & 4.4 & 4.5 \\
\hline \multicolumn{7}{|c|}{ Long-run $\bar{r}_{b}$ from equation (4) under alternative assumptions } \\
\hline $\bar{r}_{b}$, with $\bar{s}_{b}=0.47$ (2015), $\Delta_{e}=0.035$ & 1.6 & 1.8 & 2.2 & 2.3 & 2.5 & 2.6 \\
\hline $\bar{r}_{b}$, with $\bar{s}_{b}=0.59$ (CBO), $\Delta_{e}=0.035$ & 2.0 & 2.3 & 2.6 & 2.7 & 3.0 & 3.1 \\
\hline $\bar{r}_{b}$, with $\bar{s}_{b}=0.59(\mathrm{CBO}), \Delta_{e}=0.041$ & 1.8 & 2.0 & 2.4 & 2.5 & 2.7 & 2.8 \\
\hline Comparison: $\bar{r}_{b}$, 2015 TPAM report & - & 2.0 & 2.5 & - & 3.0 & - \\
\hline
\end{tabular}

Table 4 presents interest rate calculations using a range of productivity growth scenarios, with the estimates of $g$ taken from the recent literature (see Section 4 for the detailed discussion of sources and methods for growth projections). Table 4 considers two alternative assumptions on the share of debt in total wealth: $\bar{s}_{b}=0.47$ corresponding to the 2015 debt-to-GDP ratio, and $\bar{s}_{b}=0.59$ corresponding to the 2046 CBO projection of the same. Table 4 uses two alternative assumptions for the equity risk 
premium $\Delta_{e}$ : the average 1953-2015 value of 3.5 percent and the more recent, 2000-2015, average value of 4.1 percent. $^{9}$

\section{Figure 3. Scatter plots for Table 3 regression specifications}

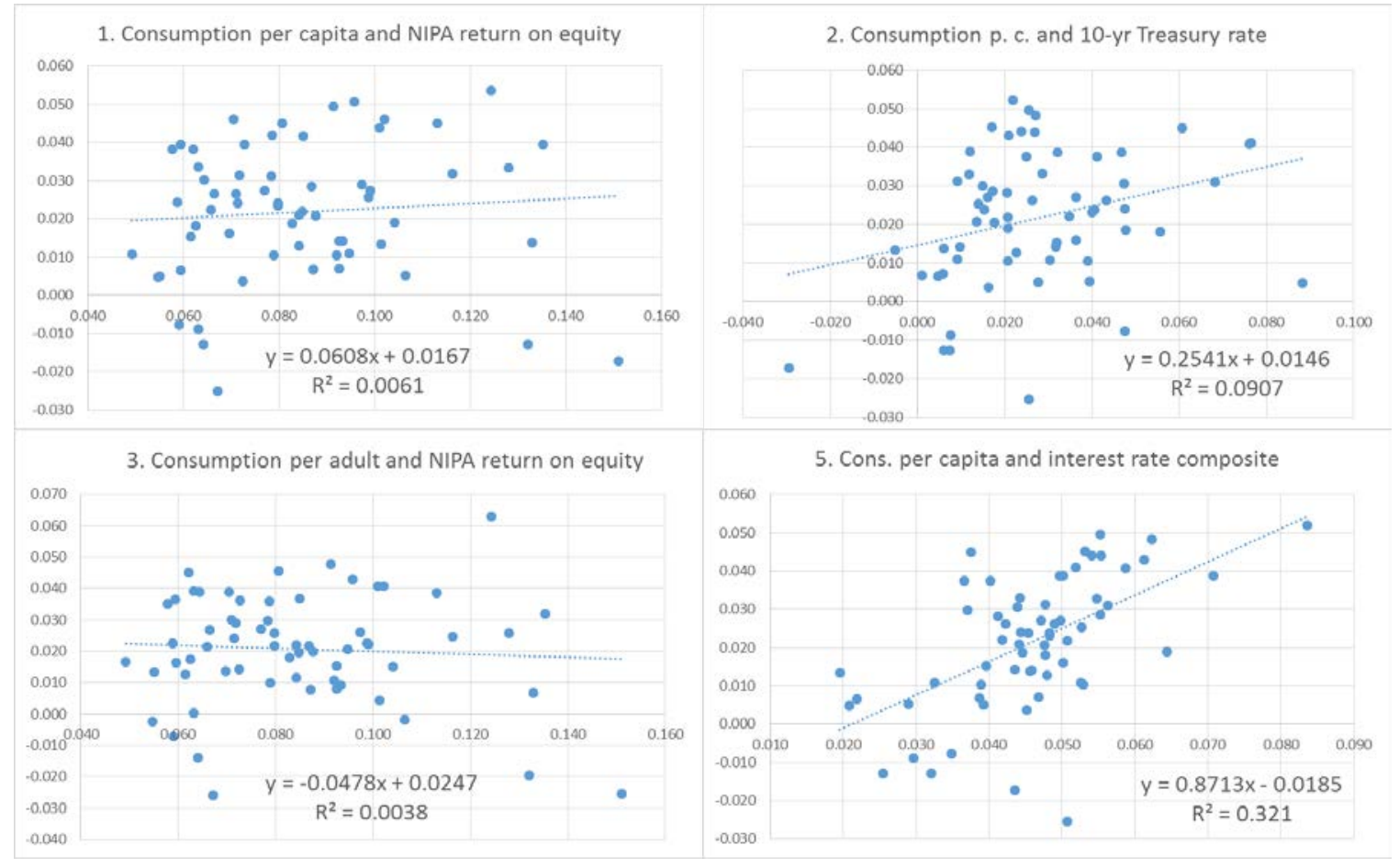

Each column of Table 4 corresponds to a separate assumption about the long-run average labor productivity growth. The assumption source is listed in the column header. The third row of the table shows the long-run interest rate composite derived from equation (3) and the point estimates of $\rho$ and $1 / \sigma$ from Table 3 averaged across specifications 4-6.

Discussion The baseline scenario for the long-run interest rate is row 6 of Table 4 (shown in bold). This scenario reflects two key assumptions: (i) the future public debt-to-GDP ratio will increase in line with the CBO 30-year projections, and (ii) the equity premium will revert back to its historical average in the long-run.

\footnotetext{
${ }^{9}$ Several arguments in the recent literature reviewed in Section 2.2 point out that some factors driving the high recent equity premium might be temporary. Accordingly, there are reasons to prefer the historical average equity premium as a proxy for the long-run future equity premium over an extrapolation from recent trends.
} 
Other scenarios in Table 4 examine departures from these assumptions. For example, if the expected increase in US government borrowing does not realize and debt-to-GDP ratio stays at its 2015 level, the long-run interest rate corresponding to the intermediate-cost productivity growth scenario would be 40 basis points lower, at 2.2 percent instead of 2.6 percent. If the factors making the recent equity premium high - the saving glut and the secular stagnation, for example - persist in the long-run, then the long-run interest rate will be 20 basis points lower, at 2.4 percent instead of 2.6 percent.

The future trajectory for US government debt changes the projections appreciably. CBO projects a rising debt-to-GDP ratio over the next 30 years, which means that an ever larger share of private wealth may be held in the form of government bonds. Households would require a higher interest rate on debt in order to hold the debt-heavy aggregate portfolio while maintaining expenditure growth equal to productivity growth. Accordingly, increased borrowing by the US government - as projected by CBO for 2016-2046 - would require that the interest rate on bonds rise by 40-50 basis points (compare rows 5 and 6 of Table 4).

The long-run interest rate also depends on the future equity premium which currently exceeds its historical average by 60 basis points. If conditions that are thought to have caused the current equity premium to be high persist, the long-run interest rate $\bar{r}_{b}$ could be 20 -30 basis points lower than in the baseline scenario where the risk premium reverts to its historical average (compare rows 6 and 7 of Table 4). The future value of the equity premium is a major source of uncertainty in the projections in part because risk premia are generally not well-explained by standard asset-pricing models.

The baseline scenario (row 6) produces the intermediate-cost long-run interest rate estimate that is close to that recommended in the 2015 TPAM report (Table 11). The estimates across the productivity growth scenarios, however, differ between Table 4 and TPAM report. Table 3 estimates of $1 / \sigma$ in equation (3) imply that the long-run interest rate is somewhat less sensitive to variations ion productivity growth than 
assumed in the 2015 TPAM report. For example, 2015 TPAM report (Table 11) shows a 100 basis point difference in the interest rate between the high-cost and the low cost scenarios, whereas estimates in Table 4 indicate 70 basis point difference between the two. In other words, TPAM report assumptions implicitly use $1 / \sigma=1.66$, compared to the average point estimate of 1.14 in Table 3 above and Laubach and Williams’ [2016] point estimate of 1.3. The analysis here makes the case for assuming slightly less variance in the long-run interest rate across the productivity growth scenarios.

\subsection{Population growth and the long-run interest rate}

A global slowdown in population growth is often thought to be one of the major drivers of the recent interest rate declines (see Rachel and Smith [2015]). There are multiple mechanisms that can make the long-run interest rate depend on the population growth rate. For example, a slower labor force growth could reduce demand for investment, and population aging could affect the aggregate personal saving rate. The impact of demographic forces on the long-run interest rate can be examined in the context of a structural model.

Standard assumptions on household preferences in the neoclassical growth model yield optimality condition (2) that does not include the rate of population growth. An equally plausible but less commonly used specification of preferences assumes imperfect familial altruism - see Baker et al. [2005]. With modified household preferences, the analog of consumption Euler equation (2) becomes

$$
\Delta l n c_{t}=\sigma\left(r_{t}-\rho-\varphi n_{t}\right)
$$

where $n_{t}$ is the current population growth and $\varphi$ is the new preference parameter that theory restricts to be between 0 and 1 . The long-run interest rate then positively depends on the long-run population growth rate $n$ - the analog of equation (3) is

$$
\bar{r}=\rho+\frac{1}{\sigma} g+\varphi n
$$


Estimating equation (5) with variables defined as in specification 5 produces a $\sigma=0.88$ - virtually the same as in Table $3-$ and $\varphi=0.52$. The estimate of $\varphi$ is in the admissible range, but it is insignificant. In the end, it is not clear that model (5) fits the data better than model (2). The finding that $\varphi$ is insignificant is not surprising, since there is not much variation in the US population growth rate compared to the variation in the interest rate. Accordingly, the method used for constructing the longrun interest rate projections in Section 3 does not seem to provide a reliable gauge of whether US population growth has an effect on the interest rate. The next section revisits this question with data from multiple countries, and it proposes to assess the long-run effect of population growth on the interest rate via simulation rather than estimation.

\section{Slowing population growth and global rate of return on equity}

The purpose of this section is two-fold: to construct a measure of the rate of return on equity for a sample of 70 major world economies and to quantitatively assess the impact of slowing population growth on the world "interest rate". The analysis applies the standard aggregate production function framework to Penn World Tables data and constructs country-specific time series for the net marginal product of capital that serve as a proxy for the pre-tax rate of return on equity. The simulation exercise constructs measures of future labor force using UN population projections and iterates on countryspecific capital accumulation equations to calculate the long-run rates of return on equity by country.

\subsection{Theoretical framework}

The one-sector neoclassical growth model represents production activity with the aggregate production function. This function maps the value of productive assets and the quality-adjusted aggregate hours worked into value-added output. From a producer's perspective, the "interest rate” in the neoclassical model equals to the net rate of return on equity in the business sector. In making assumptions on the production function, I impose standard restrictions on country-specific parameters that ensure income 
inequality across countries does not explode in the long run. These restrictions call for the rate of technological progress and the capital share to be the same across countries. The production function is assumed to be Cobb-Douglas, with a capital share $\alpha=1 / 3$ and exponentially growing total factor productivity:

$$
Y_{i, t}=Z_{i} e^{g(1-\alpha) t} \cdot\left[K_{i, t}\right]^{\alpha}\left[L_{i, t}\right]^{1-\alpha}
$$

Capital and labor are accumulated according to

$$
\begin{gathered}
K_{i, t+1}=s_{i, t} Y_{i, t}+\left(1-d_{i, t}\right) K_{i, t} \\
L_{i, t+1}=\left(1+n_{i, t+1}\right) L_{i, t}
\end{gathered}
$$

where $Y_{i, t}, K_{i, t}$ and $L_{i, t}$ are country $i$ 's date- $t$ GDP, capital stock and labor force, respectively, and $d_{i, t}$ is the depreciation rate on capital. The investment rate, $s_{i, t}$, is assumed known, and it is set from country-level data. The aggregate equations above represent either the Solow model with a fixed saving rate or the canonical overlapping generations model where households make a consumption-saving choice. In the latter case, $s_{i, t}$ can be interpreted as a composite of generation-specific preference parameters for country $i$. Unlike the framework in Section 3, the model is not asked to predict trajectories for the investment rate. 
In a neoclassical economy with a Cobb-Douglas production function, the rate of return on equity equals the net marginal product of capital

$$
r_{i, t}=\alpha \frac{Y_{i, t}}{K_{i, t}}-d_{i, t}
$$

Analysis of the interest rate trends by country group is based on equation (6) above. Accordingly, in this section the terms "interest rate" and "return on equity" will be used interchangeably. We now turn to evidence relevant for understanding the world's interest rate trends.

Figure 4. Investment and national saving rates by country group, 5-year moving average.

\section{Source: PWT.}
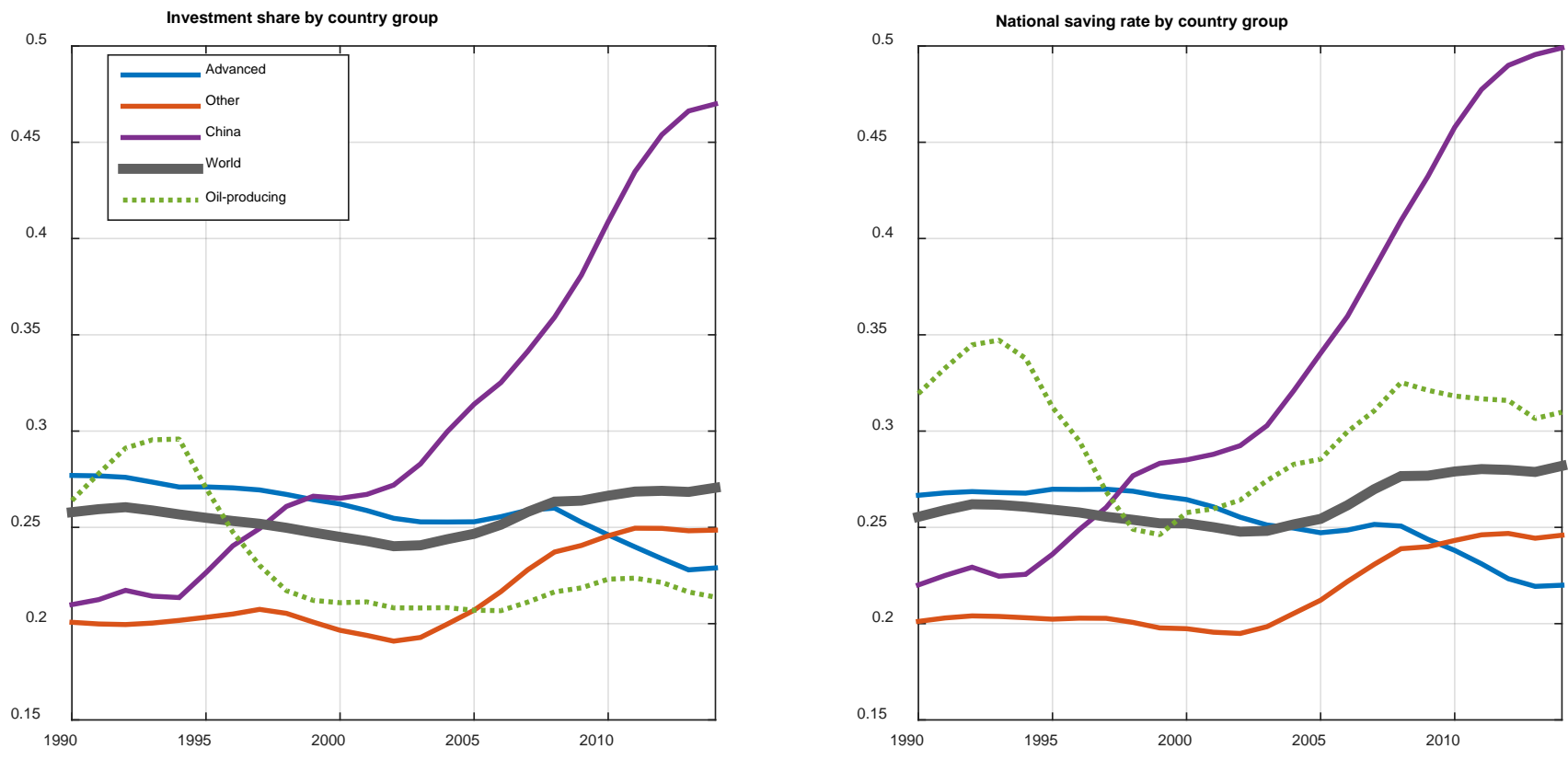


\subsection{Investment, productivity growth and world interest rate}

Analysis draws on cross-country longitudinal data from Penn World Tables (PWT) for 1990-2014. ${ }^{10}$ The goal is to document recent trends in the rate of return on equity and to investigate the sources of the “saving glut”.

SAVING AND INVESTMENT PATTERNS ACROSS THE WORLD Figure 4 shows investment and saving rates by country group and for the world as a whole during 1990-2014. The world investment rate is fairly stable over time, and it has been between 0.24 and 0.28 since 1960, despite substantial underlying imbalances in cross-country financial flows. The world investment rate did rise by 3 percentage points since 2000, largely driven by an investment boom in China. The rise in China's investment rate is truly dramatic - it more than doubled over the past 20 years, rising from 0.23 in 1994 to 0.47 in 2014. The national saving rate is even higher, as China has been accumulating foreign assets, particularly US Treasury securities. China held just 0.4 percent of total US government debt in 1994 compared to 7 percent in 2015 - a total of over 1.25 trillion dollars. China's portfolio of US securities is over 80 percent debt, perhaps indicating its role as a safe asset. By way of comparison, Canada’s 2015 portfolio of US assets is about 20 percent debt and 80 percent equity. ${ }^{11}$

The national saving rate of the "other” countries on Figure 4 - with India, Brazil, Indonesia, Turkey and Egypt being the largest economies in this group - increased from 0.19 in 2000 to 0.24 in 2014. This group accounts for about 23 percent of world GDP. Accordingly, a 5 percentage point rise in the national saving within this group contributed about 1 percent of world GDP per year to the overall "saving glut."

\footnotetext{
${ }^{10}$ The sample includes 70 largest economies in the world, together accounting for over 96 percent of global output. See Table B.3 for details.

${ }^{11}$ Source: US Department of the Treasury International Capital System (TIC) online data.
} 
Oil producers are a special group of countries whose macroeconomic aggregates strongly co-move with the world oil price. This group shows a higher-than-average investment rate in the early 1990s (see Figure 4, left panel). This is driven in part by late Soviet-era investment rates in Russia and Kazakhstan as well as by 40-plus percent investment rate of Saudi Arabia. The collapse of the Soviet Union brought an economic slump, and investment rates across the former USSR fell precipitously. Unlike the investment rate, the national saving rate of oil-producing countries shows a substantial rise during the 2000-2007 oil price run up. The oil producers account for over 11 percent of world GDP. Accordingly, an increase in the national saving of oil producers from 0.26 in 2000 to 0.31 in 2014 contributed about 0.5 percent of world GDP per year to the "saving glut".

Figure 5. Rate of return on equity and productivity trends by country group, 5-year moving average.
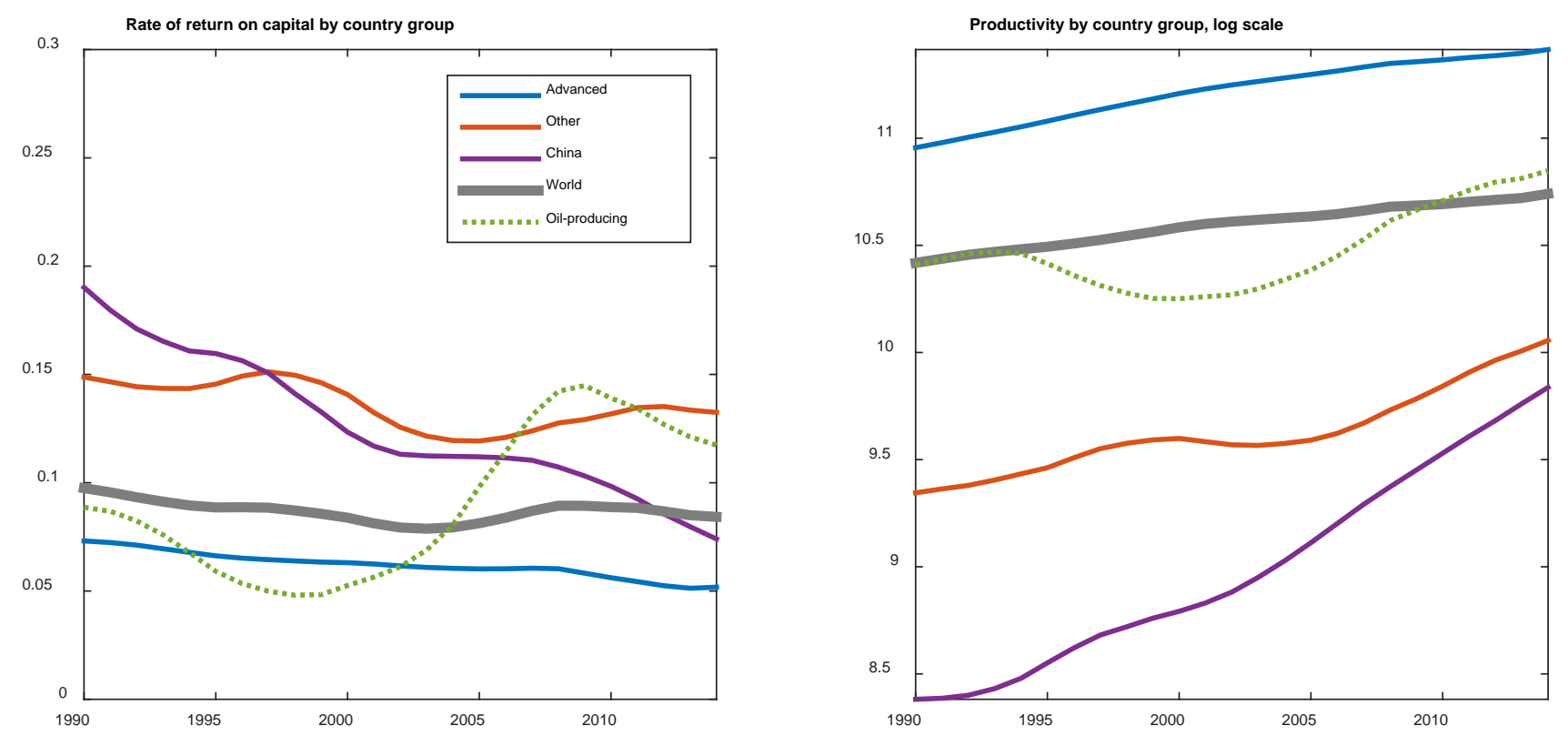

RATE OF RETURN ON EQUITY ACROSS THE WORLD In the neoclassical model, a rising investment rate leads to a higher capital output ratio and a lower return on equity. This is especially evident on Figure 5 (left panel) for China whose rate of return on equity - calculated from equation (6) -fell by over 1000 basis points between 1990 and 2014. At country level, a falling rate of return on domestic assets should 
make foreign safe assets more attractive, so it is hardly surprising that China poured its savings into US Treasuries. Capital deepening resulting from the investment boom led to rapid labor productivity convergence between China and advanced countries - see the right panel of Figure 5. Labor productivity within the "other" group experienced some catch-up as well. This catch-up, however, was not accompanied by a fall in the rate of return. This means that the "other" group experienced faster-thanaverage total factor productivity (TFP) progress during the catch-up period. For the world as a whole, the rate of return on equity fell by about 140 basis points in the 1990s and has not changed much since.

In sum, there is recent evidence of financial flow imbalances stemming in large part from rapid catch-up growth of the Chinese economy and its overall size, yet there is no clear upward or downward trend in the world's investment rate or the rate of return on equity. This does not indicate, however, that the world's interest rate will stay largely unchanged going forward. Concerns about a slowdown in the rate of TFP progress and the projected slowdown in the rate of population growth - especially in developing countries - may well have a non-negligible impact on the long-run interest rate. The next subsection proposes a quantitative investigation of the impact of productivity and population growth changes. 
Figure 6. GDP-weighted population growth projections by country group. Source: PWT and UN [2015].

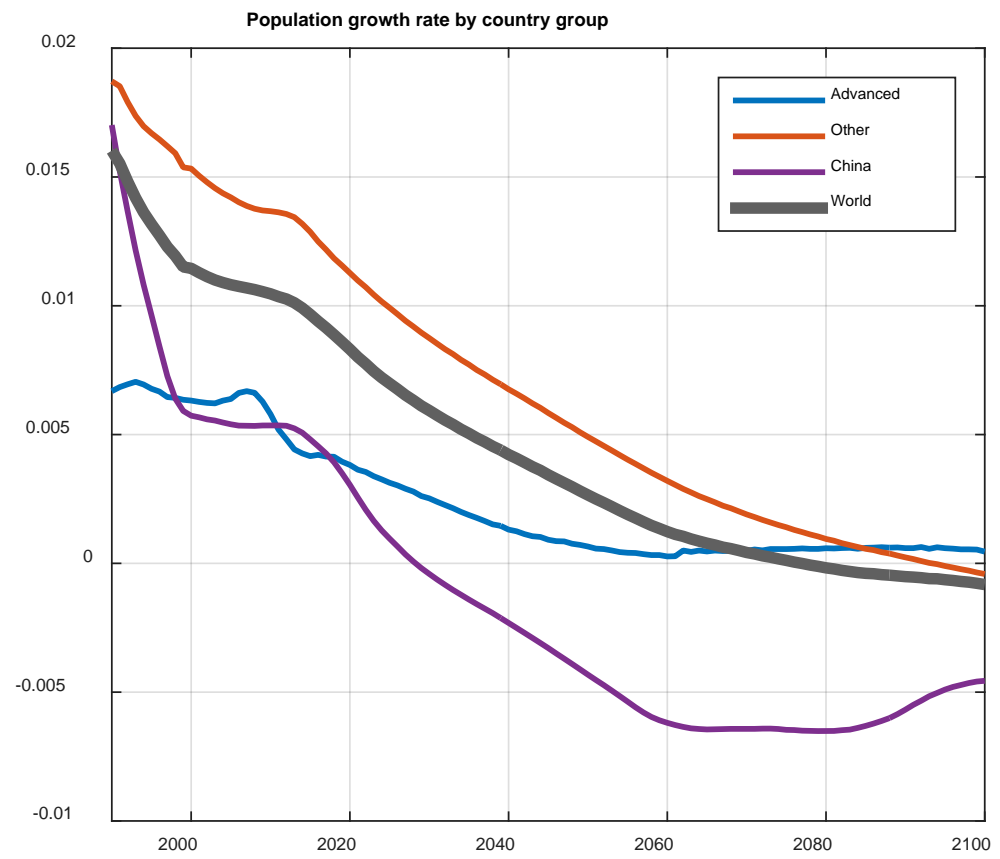

\subsection{Population growth and the long-run interest rate}

This section uses country-level population projections from the United Nations [2015] to quantitatively assess the potential impact of the expected population growth slowdown on the long-run interest rate. ${ }^{12}$ Figure 6 plots actual population growth rates for 1990-2014 and their projections until 2100 for country groups defined in Appendix Table B.3. Population growth rates of individual countries are weighted with their share in world GDP. Compared to Section 4.2, the advanced group is identical, but the oilproducing group and “other” group are merged into one.

Figure 6 shows a projected decline in the world population growth rate - from over 1.5 percent per year in 1990 to a slightly negative rate in 2100 . The population growth rate decline is especially pronounced for developing countries whose current population growth rates are high. One way to read the population projection in Figure 6 is that the world's population will essentially stabilize or will be shrinking slightly

\footnotetext{
${ }^{12}$ Source: United Nations Department of Economic and Social Affairs Population Division online data.
} 
within the next century. The population of China is projected to reach 1.4 billion by 2030 and to decline afterwards.

The long-run effect of population and productivity growth rates on the interest rate can be seen from an analytic expression when the neoclassical growth model applied to the world economy:

$$
\bar{r}=\frac{\alpha}{s}(n+g)+\left(\frac{\alpha}{s}-1\right) d
$$

In equation (7), $s$ is the weighted average investment rate, $d$ is weighted average depreciation rate, and $n$ is weighted average long-run population growth rate, with weights equal to country shares of world GDP. The first term of (7) captures the impacts of productivity and population growth rates on the longrun interest rate. When saving rate is fixed and is assumed to be unaffected by slowing productivity growth or population growth, the reduction in the long-run interest rate results solely from lower demand for investment. Accordingly, the long-run interest rate is affected just by changes in the longrun GDP growth, $n+g$. Theory restricts $s$ to be smaller than $\alpha$ in the long run. ${ }^{13}$ Accordingly, the model predicts that the impact of $n+g$ on $\bar{r}$ has to be bigger than one for one. For the world economy, one might assume that $\alpha=1 / 3$ and $s=1 / 4$, making GDP growth slowdown translate to a lower interest rate at the ratio of $\alpha / s=4 / 3$ to 1 . Notice that equations (7) and (3) both predict a similar responses of the long-run interest rate to changes in productivity growth. In equation (3), for example, the factor on $g$ is estimated to be $1 / \sigma=1.14$, and Laubach and Williams [2016] estimate the same factor to be 1.3 .

Using equation (7) to make long-range projections is not entirely appropriate, however, because the underlying assumptions might not hold over long time intervals. For example, equation (7) is derived assuming that the trend in TFP growth, $g(1-\alpha)$, is the same for all countries at all times. This

\footnotetext{
${ }^{13}$ If $s$ exceeds $\alpha$, the long-run interest rate is below the long-run GDP growth rate, $\bar{r}<g+n$. If this were the case, prices of non-reproducible assets, e.g. of land, would have to be infinite.
} 
assumption might be problematic, as documented on Figure 5: the “other” country group, for instance, has experienced a rate of TFP growth that exceeded the world average for a period of time. ${ }^{14}$ Accordingly, simulation results at shorter time horizons would be somewhat more credible.

To isolate the impact of population growth change on the interest rate, I fix a future productivity growth rate and compare two simulations. In one simulation, the population growth rate in each country is kept constant at its 2014 value going forward. In another simulation, the population growth rate is assumed to be time-varying according to the UN projections. The resulting difference is the corresponding interest rates reveals the impact of projected population growth slowdown over different time horizons.

Table 5. Long-run interest rate projections for various productivity and population growth scenarios.

\begin{tabular}{|c|l|c|c|c|}
\hline \multicolumn{2}{|c|}{ Assumptions } & \multicolumn{3}{c|}{ Interest rate projections } \\
\hline $\boldsymbol{g}$ & $\boldsymbol{n}$ & $\mathbf{2 0 1 4}$ & $\mathbf{2 0 4 0}$ & $\mathbf{2 0 7 0}$ \\
\hline 1.4 & as of 2014 & 7.9 & 6.5 & 7.4 \\
\hline 1.4 & UN projected & 7.9 & 5.9 & 5.5 \\
\hline 1.7 & as of 2014 & 7.9 & 6.8 & 7.8 \\
\hline 1.7 & UN projected & 7.9 & 6.2 & 5.9 \\
\hline 2.0 & as of 2014 & 7.9 & 7.2 & 8.2 \\
\hline 2.0 & UN projected & $\mathbf{7 . 9}$ & $\mathbf{6 . 6}$ & $\mathbf{6 . 3}$ \\
\hline 2.2 & as of 2014 & 7.9 & 7.4 & 8.6 \\
\hline 2.2 & UN projected & 7.9 & 6.8 & 6.6 \\
\hline
\end{tabular}

\footnotetext{
${ }^{14}$ Historical examples confirm that deviations from time-invariant TFP growth at country level may be quite large. For example, Hayami and Ogasawara [1999] calculate that the average rate of TFP growth in Japan was above 4 percent per year during 1958-70 and 1.5 percent per year during 1970-90.
} 
Several potentially strong assumptions have to be made to run the simulation. First, as explained above, growth rates of total factor productivity are assumed to be equal across countries. Second, future investment rates and depreciation rates are assumed to be at their historical averages. The second assumption might be less problematic since the world saving rate varies slowly and depreciation rates at country level are fairly constant as well. Third, employment to population ratios are assumed to be at their 2014 levels. This is somewhat inconsistent with the expected change in the age structure accompanying the population growth slowdown. The third assumption might be defended on the grounds that employment-to-population ratios change slowly, making the assumption a reasonable approximation over a 20-30 year time horizon.

The assumption that the saving rate is independent of the population growth rate may itself make the model overstate the effect of population growth slowdown on the interest rate. Carvalho et al. [2016] point out that increasing life expectancy and rising dependency ratio can bring about a lower aggregate saving rate and thus have a countervailing effect on the interest rate. ${ }^{15}$ If $s$ falls with $n$ in equation (7), the effect of lower GDP growth on the interest rate is mitigated.

Table 5 compares interest rate trajectories under a constant population growth scenario (setting each country's population growth rate at its 2014 value) with the same trajectories under the UN-projected population growth scenario. The difference between the two trajectories measures the impact of population growth slowdown on the world interest rate.

The interest rate values at 2040 horizon are perhaps more informative. In all scenarios, the world interest rate is projected to decline significantly in the next 25 years. The extent of the decline is $110-200$ basis

\footnotetext{
${ }^{15}$ This argument is based on the life-cycle assumption whereby the retirement period is self-financed through private saving during working years. An alternative model of retirement finance is through transfers from working family members, which is captured by a "dynastic" view of the household and produces either equation (3) or equation (5) instead of equation (7). Yang et al. [2012, Figure 5.9] find evidence supportive of the dynastic model in China: saving rates of households with elderly members are substantially higher than average.
} 
points, and it depends on the assumed productivity growth rate $g$ : a slower growth rate corresponds to a lower world interest rate, in line with equation (7).

For every productivity growth scenario in Table 5, the expected population growth slowdown contributes about 60 basis points to the interest rate decline by 2040. As explained above, this projection may overstate the impact on the interest rate, as it does not take into account the possible countervailing effect of a rising dependency ratio. If the world saving rate does fall as a result of population aging, this effect would stem the interest rate decline. Personal saving rates may also fall as more countries develop and build better social safety nets.

The total magnitude of the interest rate decline depends on assumptions about future productivity growth. World output is currently growing at over 3 percent per year, and world population is growing at roughly 1 percent per year. Both IMF and Consensus Economics forecast global GDP growth of just above 3 percent annually. Accordingly, one reasonable baseline for the future might be a 2.0 percent productivity growth rate in the world economy. The baseline scenario (shown in bold) entails a 130 basis point decline in the world interest within the next 25 years, with roughly half of this decline accounted for by the population growth slowdown.

If the world interest rates decline further, it is not clear how much of this decline will be passed through to the interest rate on the US Treasury securities. On the one hand, a lower rate of return on domestic equity might make an investment in US government bonds more attractive. On the other hand, as countries develop, their property right protections, institutions and financial markets might improve, and this, in turn, could temper demand for US safe assets. ${ }^{16}$ Understanding the influence of country-level income growth on its demand for safe assets remains an important topic for future research.

\footnotetext{
${ }^{16}$ This argument does not seem to work for Japan or Belgium - each holds over 80 percent of their US securities portfolios in Treasury bonds despite being high income countries.
} 


\section{Review and assessment of future productivity growth scenarios}

Throughout this paper, analysis used assumptions about the long-run productivity growth. This section discusses the methodologies used in constructing future productivity growth projections and highlights the sources of uncertainty that drive variance in forecasts.

\subsection{Review of future productivity growth scenarios}

This section reviews estimates of long-run average labor productivity growth appearing in the recent literature. The variance across productivity growth estimates proposed by different authors results in part from their different interpretations of historical evidence. It appears that the main disagreement between productivity growth optimists and pessimists centers around the long-run impact of information technology (IT) on productivity growth.

A common approach to productivity growth projections uses a sources of growth (SOG) decomposition. Analysis usually focuses on three sources of productivity growth: technological progress, capital deepening and growth in labor quality. For expositional purposes, it is convenient to outline the basic SOG methodology. Assume an aggregate production function with two inputs: capital, $K_{t}$, and qualityadjusted labor, $L_{t}=h_{t} N_{t}$. In the last expression, $N_{t}$ is aggregate hours worked and $h_{t}$ is a measure of labor quality that depends on average educational attainment and the composition of the labor force. Technological progress is captured by growth in total factor productivity (TFP), denoted by $Z_{t}$. Assume that the aggregate production function is Cobb-Douglas with capital share $\alpha$ :

$$
Y_{t}=Z_{t} \cdot\left[K_{t}\right]^{\alpha}\left[L_{t}\right]^{1-\alpha}
$$

The above expression gives a linear relationship between growth rates in aggregate variables,

$$
g_{Y, t}-g_{N, t}=g_{Z, t}+\alpha\left(g_{K, t}-g_{N, t}\right)+(1-\alpha) g_{h, t}
$$


The left-hand side of expression (9) is the growth rate in average labor productivity - output per hour worked. The right-hand side decomposes this growth into three sources: TFP growth, contribution of capital deepening (i.e. growth in capital stock per hour worked) and contribution of labor quality growth. Technological progress has two effects on productivity growth: it raises output directly through the production function, and it also operates indirectly, through raising investment demand and sustaining capital deepening. Put differently, ongoing technological progress is necessary for capital deepening to occur in the long run. In a model with the neoclassical aggregate production function, the long-run growth rate of capital per worker equals $g_{z} /(1-\alpha)$. Accordingly, in expression (8), the sum of direct and indirect contributions of technological progress to productivity growth is $g_{Z}+\alpha g_{Z} /(1-\alpha)=$ $g_{Z} /(1-\alpha)$. One might say that technological progress has a multiplier effect on productivity growth, with the multiplier equal to the inverse labor share, $1 /(1-\alpha)$. Note for future reference that the smaller is the labor share, the larger is the effect of capital deepening on productivity growth. We can now turn to discussing the long-run productivity growth estimates.

Several approaches to projecting future productivity growth are proposed in the recent literature. Robert Gordon [2014, 2016] proposed what might be called a subtraction approach. Gordon performs a decomposition of sources of productivity growth in the US with data going back to at least 1890, compares labor productivity growth rates over long sub-periods and subtracts contributions of factors that he believes raised labor productivity growth only temporarily. Gordon's central claim is that 19201970 was a period of exceptionally fast TFP growth. He attributes this fast TFP growth to the impact of a handful of revolutionary general purpose technologies - primarily electricity and automobile, but also indoor plumbing, household appliances, and air conditioning. ${ }^{17}$ By contrast, he argues, innovative technologies after 1970 were not general, but were "channeled into a narrow sphere of human activity

\footnotetext{
${ }^{17}$ Cowen [2011] makes a related point more forcefully by arguing that the era of major technological breakthroughs seems to be in the past.
} 
having to do with entertainment, communication and the collection and processing of information” (Gordon [2016, p. 2 and Ch. 17]). If this is true, then the slower TFP growth since 1970 - which Gordon estimates to be 0.65 percent per year - represents what one can expect from evolutionary, rather than revolutionary, innovation going forward. To translate the rate of TFP growth into its contribution to labor productivity growth, one must divide this rate the by the labor share (see equation (9) above). Table 7 below shows that the labor share is at least 0.6 . This makes the rate of productivity growth attributable to technological progress just around 1 percent annually. An additional source of long-run labor productivity growth is progress in labor quality, itself primarily due to growth in educational attainment. Gordon [2014, Section 3.2] estimates that growth in educational attainment contributed about 0.4 percent to labor productivity growth over the last century. He then projects future labor quality growth by subtracting 0.2 percent per year, pointing out recent low college completion rates and falling international test scores at the secondary-school level. ${ }^{18}$ According to Gordon's [2014] analysis, this leaves the annual projected productivity growth of 1.2 percent annually, with 1 percent contributed by a combination of TFP growth and capital deepening and 0.2 percent coming from labor quality growth. ${ }^{19}$ Gordon’s outlook for labor quality growth is fairly optimistic: in a related study, Bosler et al. [2016, Table 2] project future labor quality growth contribution between 0.1 and 0.25 percent over the next decade.

Related approaches to estimating long-run productivity growth focus more closely on the future role of information technology. Gordon [2016, Ch. 17] has argued that the productivity impact of the IT revolution was short-lived and has already happened in 1996-2004. Jorgenson et al. [2015], by contrast, start with an observation that innovation accounts for roughly 20 percent of historical productivity

\footnotetext{
${ }^{18}$ Jorgenson et al. [2015, p. 2] go as far as saying that "rising average educational attainment is about to become part of U.S. economic history".

${ }^{19}$ The growth rate of output per capita is projected to be 0.8 percent per year, which is lower that the productivity growth rate. This is because falling hours per worker and rising dependency ratio make hours per person fall at an annual rate of 0.4 percent (Gordon [2016, Table 18-4]).
} 
growth and the bulk of growth happens by replication of successful innovations. They further point out (Jorgenson et al. [2015, Figure 5]) that many US industries still have a relatively low IT intensity. Accordingly, the authors see productivity growth potential in the replication of existing technologies across more sectors through investment in equipment and software. Their projections of productivity growth rate (Jorgenson et al. [2015, pp. 19-21 and Figure 20]), however, are not much more optimistic than Gordon’s. Estimates range from 1.05 percent per year (comparable to Gordon’s long-run contribution of innovation-driven TFP growth) to 1.36 percent per year, with capital deepening accounting for most of productivity growth and labor quality growth playing almost no role.

The most optimistic long-run productivity growth projection reviewed here -1.8 percent per year - is that of Byrne et al. [2013]. Their methodology uses a multi-sector approach to growth accounting and focuses on estimating the contributions of IT-related industries to sector-specific TFP growth. The estimates (Byrne et al. [2013, Table 1]) largely confirm Gordon’s assertion that the period 1996-2004 was somewhat exceptional: the contribution of IT to aggregate productivity growth after 2004 is about the same as it was during 1974-1995. Importantly, TFP growth in IT-related sectors proceeds much faster than in the rest of the economy. In the model that Byrne et al. [2013] use to estimate future productivity growth, rapid TFP growth in a leading sector causes capital deepening that drives aggregate productivity growth. Byrne et al. extrapolate sector-specific TFP growth rates into the future ${ }^{20}$ and find that the resulting capital accumulation contributes over 1.0 percent per year to productivity growth, with TFP growth contributing 0.7 percent, and growth in labor quality contributing 0.1 percent. This result shares similarities with Jorgenson et al. [2015] in attributing a large share of productivity growth to capital deepening. Given the potentially important role of capital deepening in productivity growth,

\footnotetext{
${ }^{20}$ Byrne et al. productivity growth projection hinges, in part, on the assumption that the TFP growth in the semiconductor sector does not slow down. Bloom et al. [2016] call this assumption into question by pointing out decreasing returns to R\&D expenditure in semiconductors: achieving a doubling of transistor density on a chip requires about 25 times more research input now than it did in 1970.
} 
Section 5.2 considers further evidence on capital accumulation and focuses on alternative definitions of productive assets and investment.

In sum, optimistic growth projections hinge, in large part, on continued capital accumulation through investment in IT and communications equipment and software. Investment demand is assumed to be driven by falling cost of capital services from these assets. Recent evidence in Bloom et al. [2016] shows, however, that $R \& D$ input aimed at making capital services cheaper rises more than proportionately to the cost reductions achieved. In the end, it is not clear if the TFP growth in the leading sectors of the US economy can proceed at the same pace as before, and whether investmentdriven productivity growth will falter as a result. The next section presents evidence on historical investment patterns in the US economy.

\subsection{Intangible capital and sources of growth in the US economy}

We now take a closer look at components of business investment with the aim of using an expanded measure of intangible capital in the SOG decomposition for the US economy. This paper follows the methodology in Corrado et al. [2005, 2009, 2012] and uses disaggregated data to construct the time series for investment and stocks of capital for asset classes not covered by the NIPA.

EXPANDED DEFINITION OF INTANGIBLE ASSET CLASSES A recent body of literature (e.g. Howitt [1998], Nakamura [1999], Brynjolffson et al. [2002]) advocated incorporating expanded measures of knowledge-creating activities into national accounts. Some of the private knowledge-creating expenditures produce durable assets in the form of intellectual property. Intellectual property is an input in production that plays a role similar to physical capital. Accordingly, the categorization of expenditures on knowledge creation in the national accounts should parallel the treatment of investment in physical capital - both should be counted as expenditure on capital goods and both should be included in GDP. Fixed assets in the national accounts include several categories of intellectual property - 
capitalized $R \& D$ expenditures and the stock of software, for example. Other intangible investment expenditures - particularly, investments in firm-specific human capital and organizational structure - are treated as intermediate goods and are thus excluded.

Table 6 below presents summary statistics for intangible investment in the national accounts (NIPA) and compares them to intellectual property categories that Corrado et al. [2005] include in the expanded definition of intangible capital. Three major intangible capital classes are computerized information, innovative property and economic competencies. The last category is especially interesting, because it is not represented in the NIPA.

Table 6. Shares of intangible investment in GDP by asset class.

\begin{tabular}{|c|c|c|}
\hline Intangible capital categories & $\begin{array}{l}\text { NIPA investment } \\
\text { as a fraction of } \\
2012 \text { NIPA } \\
\text { output }\end{array}$ & $\begin{array}{l}\text { NIPA+ } \\
\text { investment as } \\
\text { fraction of } 2012 \\
\text { NIPA output }\end{array}$ \\
\hline \multicolumn{3}{|c|}{ Computerized information } \\
\hline Software & 1.76 & 1.76 \\
\hline Databases & - & 0.01 \\
\hline \multicolumn{3}{|c|}{ Innovative property } \\
\hline Mineral exploration & 0.33 & 0.39 \\
\hline Industrial R\&D & 1.62 & 1.87 \\
\hline $\begin{array}{l}\text { Entertainment and artistic } \\
\text { originals }\end{array}$ & 0.46 & 1.11 \\
\hline $\begin{array}{l}\text { New products/systems in } \\
\text { financial services }\end{array}$ & - & 0.34 \\
\hline Design and other new products & - & 0.62 \\
\hline \multicolumn{3}{|c|}{ Economic competencies } \\
\hline Brand equity & - & 1.54 \\
\hline Advertising & - & 1.34 \\
\hline
\end{tabular}




\begin{tabular}{|c|c|c|}
\hline Market research & - & 0.21 \\
\hline Firm-specific resources & - & 2.69 \\
\hline Employer-provided training & - & 1.01 \\
\hline Organizational structure & - & 1.67 \\
\hline $\begin{array}{l}\text { TOTAL, percent of 2012 NIPA } \\
\text { output }\end{array}$ & 4.17 & 14.56 \\
\hline
\end{tabular}

The single largest asset class within the economic competencies category is organization capital, and its role in productivity growth received attention in the recent literature. Brynjolffson et al. [2002], for instance, argue that investments in information technology and organization structure are complements, and that information technology raises productivity, in part, through changes in organization structures.

In terms of measurement, this paper follows Corrado et al. [2005] in assuming that investment in organizational structure equals 20 percent of aggregate managerial and executive compensation plus the total revenue of management consulting industry. The depreciation rate on organizational structure is assumed to be quite high -40 percent annually. ${ }^{21}$ This captures the fact that organizational capital is not fully owned by the firm - ownership is instead shared between the firm and its key employees (see Eisfeldt and Papanikolau [2013, 2014]). Key employee turnover then causes the firm's share of organization capital to depreciate. The assumptions in this paper can be viewed as conservative: Eisfeldt and Papanikolau [2014], for instance, assume that investment in organization capital - which, in their formulation, is shared between the firm and its key employees - equals 30 percent of selling and general administrative expense at firm level, and that its depreciation rate is 20 percent.

\footnotetext{
${ }^{21}$ Firm-specific human capital, assumed to be built with expenditures on employer-provided training, has a similarly high depreciation rate due to employee turnover.
} 
Brand equity capital built through advertising and market research is another major asset class within the economic competencies category. It is not clear, of course, to what extent advertising expenditures raise aggregate capital income. If advertising mostly re-shuffled customers across firms, for instance, its impact on aggregate output would be small. Informative advertising, however, may increase aggregate demand by better matching consumers to product varieties, and the resulting "brand loyalty" effect would help sellers sustain markups. Here, again, this paper follows Corrado et al. [2005] in making conservative assumptions: only 60 percent of total advertising expenditure is counted towards brand equity, and the depreciation rate on brand equity is set to 55 percent to account for zero-sum aspects of advertising expenditure.

Overall, Table 6 shows that NIPA+ asset classes add more than 10 percent of GDP to intangible investment, for a total of over 14 percent of GDP - roughly equal to the total amount invested in physical capital. Put differently, about 10 percent of output and over one-third of aggregate investment are not measured in the national accounts. Given the role of capital deepening generally, and intangible investment in particular, for future productivity growth (see Section 5.1), it may be informative to compare SOG decompositions between NIPA and NIPA+ concepts of investment.

SOURCES OF GROWTH IN THE US ECONOMY Productivity measurement methodology largely follows Corrado et al. [2009] and extends their sample period to $1953-2013 .^{22,23}$ Theoretically, the presence of a large unmeasured output component - 10 percent of GDP worth of intangible investment - may appreciably change the estimates of productivity growth rate, income shares and sources of growth.

\footnotetext{
${ }^{22}$ Advertising expenditure is only available until 2012; it is extrapolated to 2013 using 2012 investment shares by asset class. See Appendix B.2 for details.

${ }^{23}$ In the rate of return calculations, treatment of capital gains differs from Corrado et al. [2009]. This paper calculates the expost realized rate of return using next-year inflation as a proxy. Corrado et al. [2009] instead calculate expected capital gain from 3-year moving average inflation. Deflators used are also different from those in Corrado et al. [2009], consistent with the tax adjustment methodology. See Appendix A for details.
} 
Figure 7 presents decompositions of productivity growth into tangible and intangible capital deepening, labor quality growth and TFP growth for three historical periods - 1953-1973, 1974-1994 and 19952013. The contribution of intangible capital to productivity growth is rising over time for both NIPA and NIPA+ definitions. NIPA+ intangibles make the overall contribution of capital deepening to productivity growth substantially larger. For example, with the NIPA definition, capital deepening contributes less than half of total productivity growth during 1953-2013 whereas it explains almost 60 percent of productivity growth with NIPA+.

Figure 7. Sources of growth decompositions for NIPA and NIPA+ definitions of intangible capital.

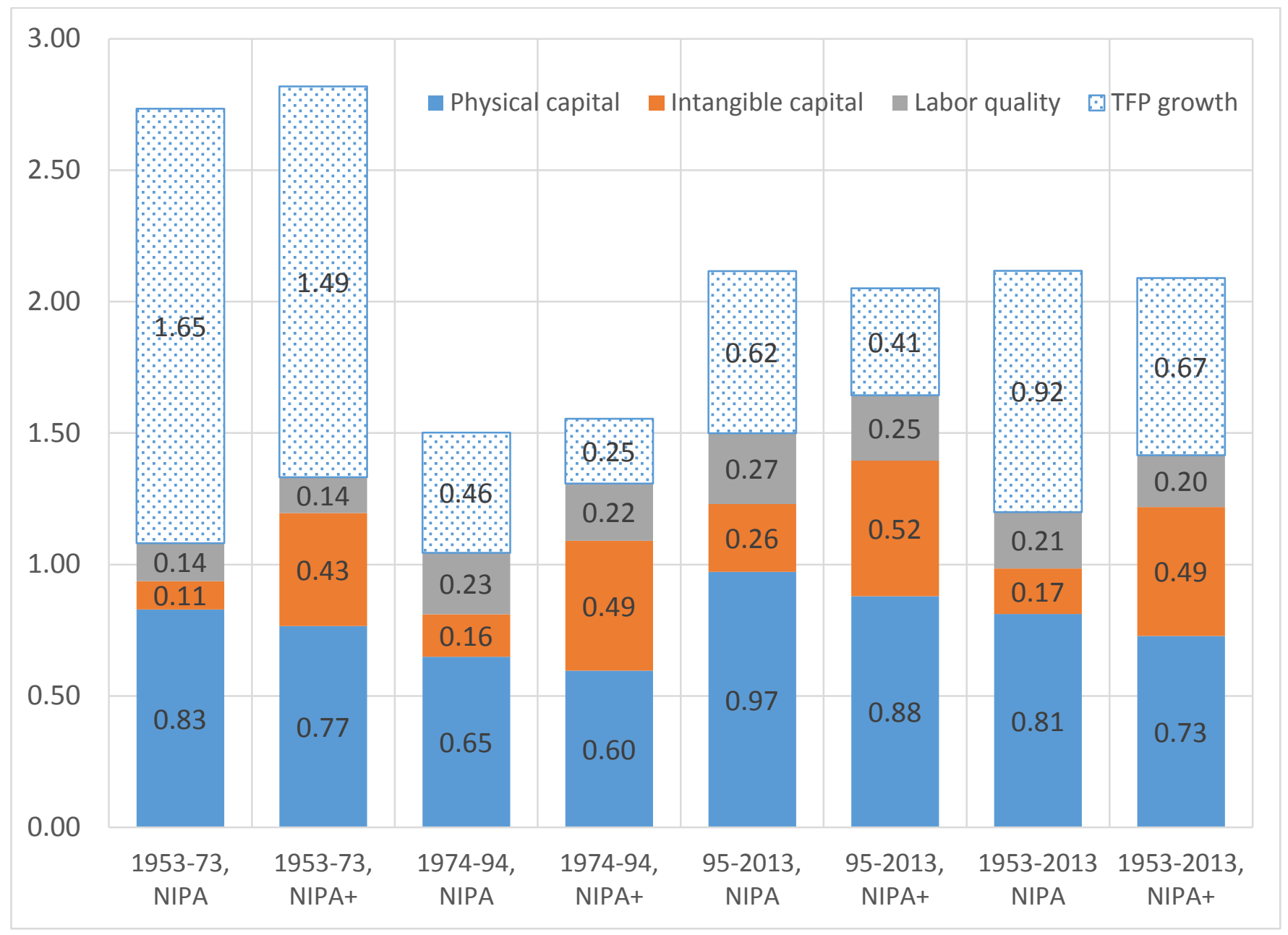

One could assess possible future productivity growth scenarios by looking at the rate of TFP growth. As explained in Section 5.1, long-run productivity growth equals the long-run rate of TFP growth divided 
by labor share. Figure 7 shows that TFP growth has been below its historical average during 1995-2013 - 0.62 percent for the NIPA decomposition (this is comparable to Gordon [2014]) and just 0.41 percent for NIPA+ (comparable to Gordon [2016, Ch 17). The difference between the two estimates is due to unmeasured investment. The NIPA TFP growth is substantially higher than that with NIPA+, because NIPA essentially attributes capital deepening from unmeasured investment to TFP growth. With labor share slightly above 0.6 (see Table 7 below), the NIPA+ sources of growth decomposition implies a 0.3 percent slower rate of long-run productivity growth than the same method using national accounts data. This adds weight to pessimistic assessments of future productivity growth. This said, NIPA+ intangible capital has been growing about 2 percent faster than output, and it added over 0.5 percent to productivity growth during 1995-2013. If intangible capital investment share in GDP does not go down, capital deepening would give productivity growth a boost in the medium run.

Table 7. Factor shares by time period.

\begin{tabular}{|l|c|c|c|c|}
\hline & $\mathbf{1 9 5 3 - 1 9 7 3}$ & $\mathbf{1 9 7 4 - 1 9 9 4}$ & $\mathbf{1 9 9 5 - 2 0 1 3}$ & $\mathbf{1 9 5 3 - 2 0 1 3}$ \\
\hline Capital share tangible, NIPA & 0.27 & 0.28 & 0.28 & 0.28 \\
\hline Capital share intangible, NIPA & 0.02 & 0.03 & 0.06 & 0.04 \\
\hline Labor share, NIPA & 0.70 & 0.68 & 0.66 & 0.68 \\
\hline Capital share tangible, NIPA+ & 0.25 & 0.25 & 0.25 & 0.25 \\
\hline Capital share intangible, NIPA+ & 0.09 & 0.10 & 0.14 & 0.11 \\
\hline Labor share, NIPA+ & 0.65 & 0.64 & 0.61 & 0.63 \\
\hline
\end{tabular}

INCOME SHARES Capital deepening matters for productivity growth more when capital share is large. Put differently, the higher is the capital share (and the lower is the labor share), the higher is the longrun productivity growth resulting from a given rate of progress in TFP. Table 7 compares factor income shares for NIPA and NIPA+ specifications and over sub-periods. 
Not surprisingly, the overall capital share is larger in the NIPA+ specification that uses an expanded definition of intangible capital - the historical averages are 0.37 with NIPA+ versus 0.32 with NIPA. In both specifications, capital share is growing slightly over time, and labor share is falling. Remarkably, in the NIPA+ specification, the share of physical capital stays roughly constant (Table 7 , line 5 ), and the rise in intangible capital share over time is offset by an equal fall in the labor share (Table 7, lines 6 and 7). The trends in income shares are consistent with the view that intangible capital has been slowly displacing labor. This brings us to a related point - productivity growth driven by task restructuring and workplace automation.

A falling labor share is the flip side of arguments supporting IT-related productivity optimism. For example, Frey and Osborne [2013] present a detailed case for a large ultimate impact of information technology through advances in robotics and artificial intelligence. At the same time, they estimate that almost a half of US jobs are at risk of automation. If capital indeed were to replace labor, productivity would grow due to shrinking labor force (i.e., $g_{N}$ in equation (9) would be negative), but the income gains will go to fewer workers, and economic inequality could rise further. Autor [2015], on the other hand, argues that automation does not necessarily shrink the labor force: income resulting from higher productivity would raise aggregate demand, and job creation could follow to meet this demand. Autor gives a historical example - replacement of the horse carriage with the automobile. On the one hand, coachman jobs disappeared. On the other hand, automobile made long-distance family travel practical, and this created a new motel and hospitality industry with numerous jobs.

To summarize, evidence reviewed here points towards increasing importance of intangible capital accumulation for productivity growth - its income share and investment share are both rising (see also Corrado et al. [2009, Figure 1]). Related, total capital share is rising as well, and this is both good news and bad news. The good news is that when capital share is large, capital deepening delivers more long- 
run productivity growth for a given rate of TFP progress. The bad news is for workers not involved in production of intangible capital - changes in organization structures made possible by information technology could require less labor input overall.

This paper's assessment of productivity growth outlook is towards the pessimistic side. As many observers noted, recent TFP growth is below its historical average. What is more, when we make a conservative adjustment for unmeasured intangible capital, the 1995-2013 aggregate TFP growth rate comes out at just 0.4 percent per year. Productivity growth projections above 1.4 percent per year hinge on a combination of two assumptions: unchanging, rapid rate of technological of progress in IT production and sustained demand for investment from IT-using industries. Recent evidence on decreasing returns to $R \& D$ expenditure in the semiconductor industry (Bloom et al. [2016]) calls the first assumption into question. Researchers are more split on assumptions about future investment demand, with Gordon [2016] and Summers [2014] representing the pessimistic side and Jorgenson et al. [2015] being more optimistic.

\section{Conclusion}

This paper develops a new measure of after-tax rate of return on aggregate wealth that maps naturally into the standard neoclassical growth model and can be useful for constructing long-run interest rate projections. The new measure is used to estimate parameters of the consumption Euler equation and to quantify the relationship between productivity growth and the interest rate in the long run. Estimates in this paper and in related studies imply that the long-run interest rate rises slightly more than one for one with productivity growth rate.

Two main sources of uncertainty affect long-run interest rate projections. The first has to do with the future rate of productivity growth. A recent body of research supports annual labor productivity growth in the 1.0-1.4 percent range going forward, although some optimistic assessments envision future 
productivity growing at 1.8 percent annually. Assumptions underlying optimistic productivity growth projections of a few years ago do not seem to be widely supported in studies that appeared since. What is more, estimates of the rate of technological progress - the ultimate driver of productivity growth may be biased upwards because of unmeasured investment in intangible capital. A sources of growth decomposition that includes unmeasured intangible capital implies a 0.3 percent slower rate of long-run productivity growth than the same method using national accounts data.

The second source of uncertainty has to do with international financial flows that contributed to recent high demand for US government bonds. Demand for US Treasury securities depends on the world interest rate that summarizes the attractiveness of investment in other assets. Several studies point out that a combination of slowing population growth and lower productivity growth would cause a slowdown in global investment demand. This paper uses UN country-level population projections and presents a range of simulations where slower growth of investment demand across the world causes the global interest rate to fall by 100-150 basis points in the next 25 years. It is unclear how much of this interest rate decline will be passed through to the US Treasury securities - the answer will depend not only on the world interest rate level, but also on global demand for safe assets generally.

Increased borrowing by the US government over the next 30 years projected by the CBO could push interest rates upwards by 40-50 basis points, partially offsetting the effects of projected global developments. All told, long-run projections with intermediate assumptions show the real interest rate on 10-year US government bonds in the 1.5-2.0 percent range. 


\section{A. Technical Appendix}

The steps below describe the derivation of the tax-adjusted rate of return on intangible capital and the construction of factor shares in an economy with tangible and intangible assets.

TAX-ADJUSTED USER COST FORMUlA Tax adjustments are based on the theoretical framework in McGrattan and Prescott [2005] that considers a neoclassical growth model with an explicit distinction between tangible and intangible capital and their separate tax treatment.

The first step is to express capital income through after-tax rate of return on equity, starting from the definition of the rate of return. Let $R_{K, t}$ denote the nominal capital income one unit ${ }^{24}$ of physical capital, $P_{K, t}$ - price index for physical capital, $\tau_{t}$ - average corporate tax rate, and $d_{K, t}$ - depreciation rate

Using the definition of the after-tax rate of return,

$$
\left(r_{e, t}+\pi_{C, t}\right) P_{K, t}=\left(1-\tau_{t}\right)\left(R_{K, t}-d_{K, t} P_{K, t}\right)+\left(P_{K, t+1}-P_{K, t}\right)
$$

\section{(A.1)}

The numerator of the above expression is nominal after-tax unit capital income net of depreciation plus the nominal capital gain on a unit of physical capital. Accordingly, the expression for nominal capital income is:

$$
R_{K, t} K_{t}=\frac{r_{e, t}+\pi_{C, t}-\pi_{K, t+1}}{1-\tau_{t}} P_{K, t} K_{t}+d_{K, t} P_{K, t} K_{t}
$$

Only corporate capital income is subject to corporate tax. Accordingly, the relationship between capital income and the rate of return for the non-corporate sector is the same as above, but with $\tau_{t}=0$. To

\footnotetext{
${ }^{24}$ A unit of measurement for real assets is a base year dollar. See Table B.1 for definitions of variables.
} 
obtain the aggregate expression for the business sector tangible assets, introduce a tax-adjustment factor that adjusts the rate of return for corporate tax only for corporate assets. Let

$$
\omega_{t}=\frac{s_{c o r p, t}}{1-\tau_{t}}+1-s_{c o r p, t}
$$

where $s_{c o r p, t}$ is the share of total physical assets in the corporate sector. Then, the aggregate tax-adjusted user cost formula that includes both corporate tax and differential taxation or corporate and noncorporate income is:

$$
R_{K, t} K_{t}=\left(r_{e, t}+\pi_{C, t}-\pi_{K, t+1}\right) \omega_{t} P_{K, t} K_{t}+d_{K, t} P_{K, t} K_{t}
$$

The user cost formula for intangible capital includes a tax adjustment to the price of intangible capital rather than the income from it. In an economy with no excess returns, the market price of one unit of intangible capital equals the cost of investment needed to build it. The after-tax cost of one unit of intangible capital is $1-\tau_{t}$ (and not 1 ), because intangible investment expenditure reduces the current corporate tax bill. By way of comparison, the cost of one unit of tangible capital is 1 , since tangible investment is not expensed. Accordingly, we have (see also McGrattan and Prescott [2005, Proposition 1]

$$
P_{M, t}=\left(1-\tau_{t}\right) P_{K, t}
$$

The owner of intangible capital pays corporate tax on intangible capital income but does not deduct intangible depreciation from the current income. The rate of return definition then gives

$$
\begin{gathered}
\left(r_{e, t}+\pi_{C, t}\right) P_{M, t}=\left(1-\tau_{t}\right) R_{M, t}-d_{M, t} P_{M, t}+\left(P_{M, t+1}-P_{M, t}\right) \Leftrightarrow \\
r_{e, t}+\pi_{C, t}=\frac{R_{M, t}-d_{M, t} P_{K, t}+\left(P_{K, t+1}-P_{K, t}\right)}{P_{K, t}}
\end{gathered}
$$


The final expressions for tangible and intangible capital incomes used in the calculation of the common after-tax rate of return $r_{e, t}$ are

$$
\begin{aligned}
& R_{K, t} K_{t}=\left(r_{e, t}+\pi_{C, t}-\pi_{K, t+1}\right) \omega_{t} P_{K, t} K_{t}+d_{K, t} P_{K, t} K_{t}, \\
& R_{M, t} M_{t}=\left(r_{e, t}+\pi_{C, t}-\pi_{M, t+1}\right) P_{K, t} M_{t}+d_{M, t} P_{K, t} M_{t} .
\end{aligned}
$$

Capital incomes on tangible and intangible assets are not observable separately, but their sum, aggregate capital income, $R_{K, t} K_{t}+R_{M, t} M_{t}$, is observable - it equals value added less labor costs and taxes:

$$
R_{K, t} K_{t}+R_{M, t} M_{t}=P_{Y, t} Y_{t}-w_{t} L_{t}-T_{Y, t}-T_{K, t}
$$

Solving the above expressions for the nominal rate of return on equity expresses $r_{e, t}$ through observables as follows:

$r_{e, t}+\pi_{C, t}=\frac{1}{\omega_{t} P_{K, t} K_{t}+P_{K, t} M_{t}}\left(P_{Y, t} Y_{t}-T_{Y, t}-T_{K, t}-D_{K, t}-D_{M, t}+\pi_{K, t+1} \omega_{t} P_{K, t} K_{t}+\pi_{K, t+1} P_{K, t} M_{t}\right)$

Notice that the tax adjustment method outlined above requires valuing units of $K$ and $M$ at a common (tax-unadjusted) price $P_{K}$. To map this formula into the national accounts data, I assume that NIPA price indices for fixed assets are similarly tax-unadjusted. Consequently, $P_{K, t} K_{t}$ and $P_{K, t} M_{t}$ would correspond to the nominal stocks of tangible and intangible assets in the NIPA, and $D_{K, t}$ and $D_{M, t}$ - to nominal consumption of tangible and intangible capital. The value of land is imputed from tax data (see Table B.1) and added to the stock of tangible capital. NIPA investment deflator is used to construct $\pi_{K}$ in expression (A.2)

The after-tax rate of return on equity, $r_{e, t}$, is calculated from (A.2) using NIPA variables constructed according to data definitions in Table B.1 (see below). 
CALCUlating FACTOR SHARES Intangible capital investments are expensed and are therefore subtracted from corporate profits. Accordingly, the construction of factor income shares attributes corporate tax to income on physical capital. This gives the following expressions for factor income shares in cost:

$$
\begin{gathered}
\alpha_{K, t}=\frac{\left(r_{e, t}+d_{K, t}+\pi_{C, t}-\pi_{K, t+1}\right) P_{K, t} K_{t}+T_{K, t}}{P_{Y, t} Y_{t}-T_{Y, t}}, \\
\alpha_{M, t}=\frac{\left(r_{e, t}+d_{M, t}+\pi_{C, t}-\pi_{K, t+1}\right) P_{K, t} M_{t}}{P_{Y, t} Y_{t}-T_{Y, t}}, \\
\alpha_{L, t}=\frac{w_{t} L_{t}}{P_{Y, t} Y_{t}-T_{Y, t}} .
\end{gathered}
$$




\section{B. Data Appendix}

\section{B.1 Construction of rate of return on assets from NIPA data}

The table below summarizes definitions of variables used in calculating the tax-adjusted rate of return on equity from equation (A.2).

\section{Table B.1. Definitions of variables}

\begin{tabular}{|c|c|c|}
\hline $\begin{array}{l}\text { Private Nonfarm business sector } \\
\text { output }\end{array}$ & $P_{Y} Y$ & $\begin{array}{l}\text { Table 1.3.5, Line } 3 \text { or BLS MPF historical } \\
\text { tables, Table } 1 \text { XG }\end{array}$ \\
\hline $\begin{array}{l}\text { Labor compensation, Private } \\
\text { Nonfarm business sector }\end{array}$ & $w L$ & MFP historical tables, Table 1 XG \\
\hline $\begin{array}{l}\text { Private non-farm business fixed } \\
\text { assets }\end{array}$ & $P_{K} K$ & $\begin{array}{l}\text { Fixed assets Table } 6.1 \\
\text { L2+L6+L7-L11 }\end{array}$ \\
\hline $\begin{array}{l}\text { Intangible assets, private non-farm } \\
\text { business sector }\end{array}$ & $P_{K} M$ & $\begin{array}{l}\text { Fixed asset table } 2.1 \\
\text { L77-L96-L97 }\end{array}$ \\
\hline $\begin{array}{l}\text { Tangible assets, private non-farm } \\
\text { business sector }\end{array}$ & & $P_{K} K_{*}=P_{K} K-P_{K} M$ \\
\hline $\begin{array}{l}\text { Private non-farm business } \\
\text { depreciation }\end{array}$ & $D_{K}+D_{M}$ & $\begin{array}{l}\text { Fixed assets Table } 6.4 \\
\text { L2+L6+L7-L11 }\end{array}$ \\
\hline Investment deflator & $P_{K}$ & Nipa table 5.3.4, L1 \\
\hline Nominal capital gains rate & $\pi_{K}$ & Growth rate of $P_{K}$ \\
\hline Corporate tax rate & $\tau$ & $\begin{array}{l}\text { Ratio of corporate taxes to corporate } \\
\text { profits less profits of federal reserve banks }\end{array}$ \\
\hline $\begin{array}{l}\text { Taxes on production and imports } \\
\text { less subsidies }\end{array}$ & $T_{Y}$ & NIPA table 1.12, L19-L20 \\
\hline Taxes on corporate income & $T_{K}$ & NIPA table 1.12, L14 \\
\hline Value of land & $P_{T} T=\theta P_{K} K_{*}$ & Imputed using tax data (see next line) \\
\hline $\begin{array}{l}\text { Value of land as a fraction of } \\
\text { tangible reproducible assets in the } \\
\text { corporate sector }\end{array}$ & $\theta$ & $\frac{\text { SOI Tax Stats - Table } 2 \text { - Returns of }}{\underline{\text { Active Corporations, L23 } \div \text { L19 }}}$ \\
\hline
\end{tabular}




\section{B.2 Data sources and assumptions used in construction of NIPA+ intangible investment}

\section{Databases}

1) Revenue data source: Subscriptions and sales for the "Directory and Mailing List Publishers" industry from SAS (https://www.census.gov/services/sas/historic_data.html)

For 2010-2013, Table 4 "Estimated Sources of Revenue for Employer Firms", subscriptions and sales.

For 1998-2009, "Sources of Revenue" table for the "Directory and Mailing List Publishers" industry (only pdf reports available). For years prior to 2005, the data is categorized between print and other media. Data for 2009-2005 taken from 2009 report, data from 2004 taken from 2006 report, data for 2001-2003 taken from 2003 report and data from 1998-2000 taken from 2000 report.

2) Missing values are imputed using the Software Investment series taken from NIPA. Section 5, Table 5.6.5. Private Fixed Investment in Intellectual Property Products by Type

\section{New products in financial system}

Corrado et al. [2005] and Corrado et al. [2012] propose two different methods

2005 Method

1) Use data on Intermediate inputs for the "Finance and insurance" industry from BEA (http://www.bea.gov/industry/gdpbyind_data.htm).

2) Multiple by 0.2, as explained by Corrado et al. [2005] table 1.3, item 6a: "New product development costs in the financial services industries, crudely estimated as 20 percent of intermediate purchases." 


\section{$\underline{2012 \text { Method }}$}

This method follows Corrado et al. [2012], as explained in the footnotes to their table 3, page 30.

1) Calculate total compensation in the Finance and Insurance industry for STEM occupations (sciences (life, physical, social), computer science, engineering, or mathematics) plus quantitative finance occupations (accountants, actuaries, statisticians, financial quantitative analysts, and risk management specialists) and STEM managers. Data is taken from BLS - "National industry-specific" occupational employment statistics (http://www.bls.gov/oes/tables.htm).

2) Multiply item 1 compensation by 0.5. According to Corrado et al. [2012] table 3, “These NPD estimates are based on 50 percent of the labor compensation of included occupations”.

3) Add to compensation the value for "Purchased R\&D services by financial services industries". Calculated as: 3.3 percent of the total revenue of the R\&D services industry (NAICS 5417) (Corrado et al. [2012, Table 3]). Data for Revenues in the R\&D services industry is from SAS reports 2013, 2006 and 1999 Total Revenues for "R\&D Services" Industry

\section{(https://www.census.gov/services/sas/historic_data.html).}

4) Subtract reported $R \& D$ costs in the financial services industry. These costs can be found as the Purchased component reported in the Financial Services and Insurance industry R\&D satellite account (http://www.bea.gov/national/rd.htm). The dataset to use is "1998-2007 research and development data". Values from 2008-2013 imputed using average growth rate from 2003-2008.

5) Inflate these values using a markup to account for materials use. The markup is calculated as an average of the materials share in Value added of "Finance and insurance" industry and the materials 
share in the "computer systems design and related services" industry (NAICS 5415). Data on materials

from BEA: KLEMS data 1997-2014 (http://www.bea.gov/industry/gdpbyind_data.htm). ${ }^{25}$

6) Impute missing values using value added for the "Financial Services and Insurance" Industry from BEA.

\section{Design and Other New Product Systems}

1) Data taken from SAS 1998-2013: Revenue of employer firms for the "Architectural and Engineering designs" industry and Revenue of employer firms for the "R\&D in Social Sciences" industry (https://www.census.gov/services/sas/historic_data.html).

2) Following Corrado et al. [2005], Table 1.3, Item 6, calculate intangible investment as $0.5 *$ Revenues in "Architectural and Engineering designs" and 2*Revenues in "R\&D in Social Sciences".

3) Impute data for missing years using Industry Value Added data from BEA from "Miscellaneous professional, scientific, and technical services" industry

(http://www.bea.gov/industry/gdpbyind_data.htm). File: Value Added 1947-2015: up to 71 Industries (XLSX).

\section{Advertising}

1) Data is from Robert Coen Universal Report for McCann, p. 8, Table Worldwide Ad Growth 19902007.

\footnotetext{
25 Note that this item is slightly different than the one suggested by Corrado et al. [2012]. They state "The markup is based on an average of the materials share in BEA's R\&D satellite account for financial services and the share in the computer systems design and related services industry (NAICS 5415)”. Since materials are not reported anywhere for the financial services industry in the R\&D satellite account, we used the share of materials to value added in the financial services and insurance industry instead.
} 
2) Multiply the advertising expenditure figure by 0.6 following Corrado et al. [2009], p. 670: "Based on results from the empirical literature on advertising, we estimated that only about 60 percent of total advertising expenditures were for ads that had long-lasting effects”.

3) Impute values before and after using Industrial R\&D series for 1953-2007, for 2012 use (http://www.nsf.gov/statistics/srvyindustry/) and for 2008-2011 use World Bank Data on R\&D. As World Bank data includes private and public, use data from 1996-2007 to calculate the share of private to public R\&D and then apply it to the 2008-2011 period.

\section{$\underline{\text { Market Research }}$}

1) Main data taken from SAS 1998-2013, Revenue of employer firms for the "Marketing Research and Public Opinion Polling" industry (https://www.census.gov/services/sas/historic_data.html).

2) According to Corrado et al. [2005], Table 1.3, Item 7, calculate intangible investment as $2 *$ Revenues in "Marketing Research and Public Opinion Polling".

3) For missing years impute using Industry Value Added data from BEA from the " Miscellaneous professional, scientific, and technical services" industry

(http://www.bea.gov/industry/gdpbyind_data.htm). File: Value Added 1947-2015: up to 71 Industries (XLSX).

\section{Employer-provided Training}

This category has two components: Wages and Salary costs (Indirect costs) and Direct Costs. 
Indirect Costs:

1) Use BLS Survey from 1995 and get Wage and Salary Costs per employee by industry (http://www.bls.gov/news.release/sept.t11.htm).

2) Use BEA data for the number of employees (full time and part time) and aggregate them by industry to match the industries in BLS: 1948-1997 (http://www.bea.gov/industry/more.htm) and 1998-2014 from NIPA table 6.4D

(http://www.bea.gov/iTable/iTable.cfm?ReqID=9\&step=1\#reqid=9\&step=3\&isuri=1\&903=193).

3) Deflate wages using the Price Index for "Private Industries" from the BEA (http://www.bea.gov/industry/gdpbyind_data.htm).

Direct Costs:

1) Take training raining costs per employee by industry from 1995 BLS survey (http://www.bls.gov/news.release/sept1.t07.htm).

2) Use BEA data for the number of employees (full time and part time) and aggregate them by industry to match the industries in BLS: 1948-1997 (http://www.bea.gov/industry/more.htm) and 1998-2014 from NIPA table 6.4D

(http://www.bea.gov/iTable/iTable.cfm?ReqID=9\&step=1\#reqid=9\&step=3\&isuri=1\&903=193).

3) Deflate wages using the Price Index for the "Educational Services" Industry GDP from the BEA (http://www.bea.gov/industry/gdpbyind_data.htm).

\section{Organizational Structure}

This category has two components, "Purchased” and "Own”: 


\section{Purchased:}

1) Main data is from SAS 1998-2013, Revenue of employer firms for the "Management Consulting Services" industry (https://www.census.gov/services/sas/historic_data.html).

2) For missing years, impute using Industry Value Added data from BEA from the "Miscellaneous professional, scientific, and technical services" industry, File of Value Added 1947-2015: up to 71 Industries (XLSX) (http://www.bea.gov/industry/gdpbyind_data.htm) .

Own:

1) For each year 1999-2015, use data on mean wages and employees in executive occupations from BLS "National" dataset (http://www.bls.gov/oes/tables.htm).

2) Multiply executive compensation by 0.2 following the assumption in Corrado et al. [2005, p. 29]: "If just one-fifth of management time is spent on organizational innovation ...”

3) Impute values before and after using Industrial R\&D series for 1953-2007, for 2012 use (http://www.nsf.gov/statistics/srvyindustry/) and for 2008-2011 use World Bank Data on R\&D. As World Bank data includes private and public, use data from 1996-2007 to calculate the share of private to public R\&D and then apply it to the 2008-2011 period. 


\section{B.3 International data from Penn World Tables}

Table B.3. Sample of 70 world's largest economies by output share and country group. Source: PWT.

\begin{tabular}{|c|c|c|c|c|c|c|c|c|c|}
\hline Country & $\begin{array}{c}2014 \\
\text { outp } \\
\text { ut } \\
\text { rank }\end{array}$ & $\begin{array}{c}\text { Country } \\
\text { group }\end{array}$ & $\begin{array}{c}2014 \\
\text { world } \\
\text { PPP } \\
\text { output } \\
\text { share }\end{array}$ & $\begin{array}{c}\text { Cum } \\
\text { PPP } \\
\text { world } \\
\text { output } \\
\text { share }\end{array}$ & Country & $\begin{array}{c}2014 \\
\text { outp } \\
\text { ut } \\
\text { rank }\end{array}$ & $\begin{array}{c}\text { Country } \\
\text { group }\end{array}$ & $\begin{array}{c}2014 \\
\text { world } \\
\text { PPP } \\
\text { output } \\
\text { share }\end{array}$ & $\begin{array}{c}\text { Cum } \\
\text { PPP } \\
\text { world } \\
\text { output } \\
\text { share }\end{array}$ \\
\hline China & 1 & China & 0.165 & 0.165 & Venezuela & 36 & Oil-prod. & 0.005 & 0.863 \\
\hline United States & 2 & $\begin{array}{l}\text { Advance } \\
\text { d }\end{array}$ & 0.159 & 0.324 & Bangladesh & 37 & Other & 0.004 & 0.867 \\
\hline India & 3 & Other & 0.068 & 0.392 & Ukraine & 38 & Other & 0.004 & 0.872 \\
\hline Japan & 4 & $\begin{array}{l}\text { Advance } \\
\mathrm{d}\end{array}$ & 0.043 & 0.435 & Belgium & 39 & $\begin{array}{l}\text { Advance } \\
\mathrm{d}\end{array}$ & 0.004 & 0.876 \\
\hline Germany & 5 & $\begin{array}{l}\text { Advance } \\
\mathrm{d}\end{array}$ & 0.036 & 0.471 & Iraq & 40 & Oil-prod. & 0.004 & 0.880 \\
\hline Russian Fed. & 6 & Oil-prod. & 0.033 & 0.504 & Sweden & 41 & $\begin{array}{l}\text { Advance } \\
\mathrm{d}\end{array}$ & 0.004 & 0.884 \\
\hline Brazil & 7 & Other & 0.029 & 0.534 & Kazakhstan & 42 & Oil-prod. & 0.004 & 0.888 \\
\hline France & 8 & $\begin{array}{l}\text { Advance } \\
\text { d }\end{array}$ & 0.025 & 0.558 & Norway & 43 & $\begin{array}{l}\text { Advance } \\
\mathrm{d}\end{array}$ & 0.004 & 0.892 \\
\hline $\begin{array}{l}\text { United } \\
\text { Kingdom }\end{array}$ & 9 & $\begin{array}{l}\text { Advance } \\
\mathrm{d}\end{array}$ & 0.024 & 0.582 & Romania & 44 & Other & 0.004 & 0.896 \\
\hline Indonesia & 10 & Other & 0.024 & 0.606 & Austria & 45 & $\begin{array}{l}\text { Advance } \\
\mathrm{d}\end{array}$ & 0.004 & 0.900 \\
\hline Italy & 11 & $\begin{array}{l}\text { Advance } \\
\mathrm{d}\end{array}$ & 0.020 & 0.626 & Chile & 46 & Other & 0.004 & 0.903 \\
\hline Mexico & 12 & Oil-prod. & 0.019 & 0.645 & Singapore & 47 & $\begin{array}{l}\text { Advance } \\
\mathrm{d}\end{array}$ & 0.004 & 0.907 \\
\hline $\begin{array}{l}\text { Rep. of } \\
\text { Korea }\end{array}$ & 13 & $\begin{array}{l}\text { Advance } \\
\text { d }\end{array}$ & 0.017 & 0.662 & Peru & 48 & Other & 0.003 & 0.910 \\
\hline Canada & 14 & $\begin{array}{l}\text { Advance } \\
\mathrm{d}\end{array}$ & 0.015 & 0.677 & Qatar & 49 & Other & 0.003 & 0.913 \\
\hline Turkey & 15 & Other & 0.015 & 0.691 & Hong Kong & 50 & $\begin{array}{l}\text { Advance } \\
\mathrm{d}\end{array}$ & 0.003 & 0.916 \\
\hline Spain & 16 & $\begin{array}{l}\text { Advance } \\
\text { d }\end{array}$ & 0.015 & 0.706 & Czech Rep. & 51 & $\begin{array}{l}\text { Advance } \\
\mathrm{d}\end{array}$ & 0.003 & 0.919 \\
\hline Saudi Arabia & 17 & Oil-prod. & 0.014 & 0.720 & Myanmar & 52 & Other & 0.003 & 0.922 \\
\hline Iran & 18 & Oil-prod. & 0.012 & 0.732 & Portugal & 53 & $\begin{array}{l}\text { Advance } \\
\text { d } \\
\end{array}$ & 0.003 & 0.925 \\
\hline Australia & 19 & $\begin{array}{l}\text { Advance } \\
\text { d }\end{array}$ & 0.010 & 0.742 & Greece & 54 & $\begin{array}{l}\text { Advance } \\
\mathrm{d}\end{array}$ & 0.003 & 0.928 \\
\hline Nigeria & 20 & Oil-prod. & 0.010 & 0.752 & Kuwait & 55 & Oil-prod. & 0.002 & 0.930 \\
\hline Taiwan & 21 & $\begin{array}{l}\text { Advance } \\
\text { d }\end{array}$ & 0.009 & 0.761 & Israel & 56 & $\begin{array}{l}\text { Advance } \\
\text { d }\end{array}$ & 0.002 & 0.932 \\
\hline Egypt & 22 & Other & 0.009 & 0.770 & Denmark & 57 & $\begin{array}{l}\text { Advance } \\
\text { d }\end{array}$ & 0.002 & 0.935 \\
\hline Poland & 23 & Other & 0.009 & 0.779 & Morocco & 58 & Other & 0.002 & 0.937 \\
\hline
\end{tabular}




\begin{tabular}{|c|c|c|c|c|c|c|c|c|c|}
\hline Thailand & 24 & Other & 0.009 & 0.788 & Uzbekistan & 59 & Other & 0.002 & 0.940 \\
\hline Pakistan & 25 & Other & 0.009 & 0.797 & Ireland & 60 & $\begin{array}{l}\text { Advance } \\
\text { d }\end{array}$ & 0.002 & 0.942 \\
\hline Argentina & 26 & Other & 0.008 & 0.805 & Hungary & 61 & Other & 0.002 & 0.944 \\
\hline Netherlands & 27 & $\begin{array}{l}\text { Advance } \\
\mathrm{d}\end{array}$ & 0.008 & 0.813 & Sri Lanka & 62 & Other & 0.002 & 0.946 \\
\hline Philippines & 28 & Other & 0.006 & 0.819 & Angola & 63 & Oil-prod. & 0.002 & 0.948 \\
\hline South Africa & 29 & Other & 0.006 & 0.826 & Finland & 64 & $\begin{array}{l}\text { Advance } \\
\mathrm{d}\end{array}$ & 0.002 & 0.950 \\
\hline Malaysia & 30 & Other & 0.006 & 0.832 & Belarus & 65 & Other & 0.002 & 0.952 \\
\hline $\begin{array}{l}\text { United Arab } \\
\text { Emir }\end{array}$ & 31 & Oil-prod. & 0.006 & 0.838 & $\begin{array}{l}\text { Former } \\
\text { Sudan }\end{array}$ & 66 & Other & 0.002 & 0.954 \\
\hline Colombia & 32 & Other & 0.006 & 0.844 & Ecuador & 67 & Other & 0.002 & 0.956 \\
\hline Switzerland & 33 & $\begin{array}{l}\text { Advance } \\
\mathrm{d}\end{array}$ & 0.005 & 0.849 & Oman & 68 & Oil-prod. & 0.002 & 0.957 \\
\hline Algeria & 34 & Other & 0.005 & 0.854 & Azerbaijan & 69 & Other & 0.001 & 0.959 \\
\hline Viet Nam & 35 & Other & 0.005 & 0.858 & $\begin{array}{l}\text { New } \\
\text { Zealand }\end{array}$ & 70 & $\begin{array}{l}\text { Advance } \\
\mathrm{d}\end{array}$ & 0.001 & 0.960 \\
\hline
\end{tabular}




\section{References}

Ait-Sahalia, Yacine, Jonathan A. Parker, and Motohiro Yogo. "Luxury Goods and the Equity Premium.” The Journal of Finance 59, no. 6 (2004): 2959-3004.

Autor, David H. "Why Are There Still So Many Jobs? The History and Future of Workplace Automation.” Journal of Economic Perspectives 29, no. 3 (August 2015): 3-30.

Baker, Dean, J. Bradford De Long, and Paul R. Krugman. “Asset Returns and Economic Growth.” Brookings Papers on Economic Activity 2005, no. 1 (2005): 289-330.

Beaudry, Paul, David A. Green, and Benjamin M. Sand. “The Great Reversal in the Demand for Skill and Cognitive Tasks.” Working Paper. National Bureau of Economic Research, March 2013.

Bernanke, Ben S., Carol Bertaut, Laurie Pounder DeMarco, and Steven Kamin, “International Capital Flows and the Returns to Safe Assets in the United States, 2003-2007.” Technical Report 1014, Federal Reserve Board, February 2011. International Finance Discussion Papers.

Blanchard, Olivier J., and Lawrence H. Summers. "Perspectives on High World Real Interest Rates.” Brookings Papers on Economic Activity 15, no. 2 (1984): 273-334.

Bloom, Nicholas, Jones, Charles, Van Reenen, John, and Webb, Michael. “Are Ideas Getting Harder to Find?,” mimeo, Stanford University, November 2016.

Bosler, Canyon, Mary C. Daly, John G. Fernald, and Bart Hobijn. “The Outlook for U.S. Labor-Quality Growth.” Working Paper. National Bureau of Economic Research, August 2016.

Brynjolfsson, Erik, Lorin M. Hitt, and Shinkyu Yang. 2002. "Intangible assets: Computers and organizational capital.” Brookings Papers on Economic Activity, Macroeconomics: 137-99.

Byrne, David M., Stephen D. Oliner, and Daniel E. Sichel. “Is the Information Technology Revolution Over?” International Productivity Monitor 25 (2013): 20-36. 
Caballero, Ricardo J., Emmanuel Farhi, and Pierre-Olivier Gourinchas. “An Equilibrium Model of ‘Global Imbalances’ and Low Interest Rates.” American Economic Review 98, no. 1 (March 2008): 358-93.

Caballero, Ricardo J., and Emmanuel Farhi. “The Safety Trap.” Working Paper. National Bureau of Economic Research, February 2014.

Calvert, Laurent, John Y. Campbell, Francisco Gomes, and Paolo Sodini. “The Cross-Section of Household Preferences,” working paper, University of Texas, April 2016

Carvalho, Carlos, Andrea Ferrero, and Fernanda Nechio. “Demographics and Real Interest Rates: Inspecting the Mechanism.” European Economic Review, vol. 88, Sep 2016, pp. 208-26.

Corrado, Carol, John C. Haltiwanger, Daniel E. Sichel, and Conference on Research in Income and Wealth, eds. Measuring Capital in the New Economy. Studies in Income and Wealth, v. 65. Chicago: University of Chicago Press, 2005.

Corrado, Carol, Charles Hulten, and Daniel Sichel. “Intangible Capital and U.S. Economic Growth.” Review of Income and Wealth 55, no. 3 (September 1, 2009): 661-85.

Corrado, Carol, Jonathan Haskel, Cecilia Jona-Lasinio, Massimiliano Iommi, and others. Intangible Capital and Growth in Advanced Economies: Measurement Methods and Comparative Results. IZA, 2012.

Cowen, Tyler. (2011). The great stagnation: how America ate all the low-hanging fruit of modern history, got sick, and will (eventually) feel better. New York: Dutton.

Eggertsson, Gauti B., Neil R. Mehrotra, and Lawrence H. Summers. “Secular Stagnation in the Open Economy.” Working Paper. National Bureau of Economic Research, April 2016. 
Eichengreen, Barry. "Secular Stagnation: The Long View." Working Paper. National Bureau of Economic Research, January 2015.

Eisfeldt, Andrea L., and Dimitris Papanikolaou. “Organization Capital and the Cross-Section of Expected Returns.” The Journal of Finance 68, no. 4 (August 1, 2013): 1365-1406.

Eisfeldt, Andrea L., and Dimitris Papanikolaou. “The Value and Ownership of Intangible Capital.” American Economic Review 104, no. 5 (May 2014): 189-94. doi:10.1257/aer.104.5.189.

Frey, Carl B., and Osborne, Michael. “The Future of Employment: How Susceptible are Jobs to Computerisation?” Oxford Martin School working paper, 2013.

Gordon, Robert J. “The Demise of US Economic Growth: Restatement, Rebuttal, and Reflections.” National Bureau of Economic Research, 2014.

Gordon, Robert J. The Rise And Fall of American Growth: The U.S. Standard of Living Since the Civil War. Princeton, NJ: Princeton University Press, 2016.

Hall, Robert E. “Intertemporal Substitution in Consumption.” Journal of Political Economy 96, no. 2 (1988): 339-57.

Hall, Robert E. “Understanding the Decline in the Safe Real Interest Rate.” Working Paper. National Bureau of Economic Research, April 2016.

Hayami, Yujiro, and Junichi Ogasawara. “Changes in the Sources of Modern Economic Growth: Japan Compared with the United States.” Journal of the Japanese and International Economies 13, no. 1 (March 1, 1999): 1-21.

Howitt, Peter, “Measurement, Obsolescence, and General Purpose Technologies”, in Helpman, Elhanan, ed., General purpose technologies and economic growth, (Cambridge and London: MIT Press, 1998) 219-51. 
International Monetary Fund. “Perspectives on World Real Interest Rates.”, IMF World Economic Outlook, Chapter 3, April 2014.

Jorgenson, Dale, Mun Ho, and Jon Samuels. "Education, Participation, and the Revival of U.S. Economic Growth.” NBER Chapters. National Bureau of Economic Research, 2015.

Karabarbounis, Loukas, and Brent Neiman. “The Global Decline of the Labor Share.” National Bureau of Economic Research, 2013.

Kocherlakota, Narayana R. “On Tests of Representative Consumer Asset Pricing Models.” Journal of Monetary Economics 26, no. 2 (1990): 285-304.

Kocherlakota, Narayana R. “The Equity Premium: It’s Still a Puzzle.” Journal of Economic Literature 34, no. 1 (1996): 42-71.

King, Mervyn, and David Low. "Measuring The"world"real Interest Rate." National Bureau of Economic Research, 2014.

Kocherlakota, Narayana. “On Tests of Representative Consumer Asset Pricing Models.” Journal of Monetary Economics 26, no. 2 (1990): 285-304.

Kocherlakota, Narayana R. “The Equity Premium: It’s Still a Puzzle.” Journal of Economic Literature 34, no. 1 (1996): 42-71.

Laubach, Thomas, and John C. Williams. "Measuring the Natural Rate of Interest." Review of Economics and Statistics 85, no. 4 (November 1, 2003): 1063-70.

Laubach, Thomas, and John C. Williams. “Measuring the Natural Rate of Interest Redux.” Finance and Economics Discussion Series. Board of Governors of the Federal Reserve System (U.S.), 2016.

McGrattan, Ellen R., and Edward C. Prescott. “Taxes, Regulations, and the Value of US and UK Corporations.” The Review of Economic Studies 72, no. 3 (2005): 767-796. 
McGrattan, Ellen R., and Edward C. Prescott. "Data Appendix: Taxes, Regulations, and the Value of US and UK Corporations”, Federal Reserve Bank of Minneapolis staff report 309, June 2004.

Nakamura, Leonard. 1999. “Intangibles: What put the new in the new economy?” Federal Reserve Bank of Philadelphia Business Review (July/August): 3-16.

Rachel, Lukasz, and Thomas Smith. "Secular Drivers of the Global Real Interest Rate”, Bank of England Staff Working Paper No. 571 (Dec 2015).

Summers, Lawrence H. "U.S. Economic Prospects: Secular Stagnation, Hysteresis, and the Zero Lower Bound.” Business Economics 49, no. 2 (April 1, 2014): 65-73.

Yang, Dennis Tao, Junsen Zhang, and Shaojie Zhou. “Why Are Saving Rates So High in China?” in Capitalizing China, Joseph P. H. Fan and Randall Morck, eds., University of Chicago Press, November 2012. 